Article

\title{
Scion $\times$ Rootstock Response on Production, Mineral Composition and Fruit Quality under Heavy-Calcareous Soil and Hot Climate
}

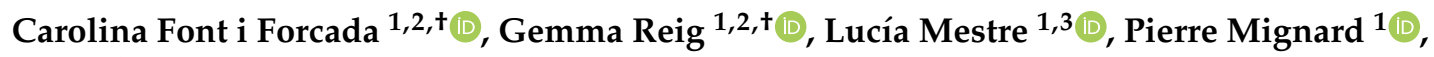 \\ Jesús Ángel Betrán ${ }^{3}$ and María Ángeles Moreno ${ }^{1, *(\mathbb{D})}$ \\ 1 Department of Pomology, Experimental Station of Aula Dei-CSIC (Spanish National Research Council), \\ Apdo. 13034, 50080 Zaragoza, Spain; lucia.mesones@gmail.com (L.M.); pmignard@eead.csic.es (P.M.) \\ 2 IRTA Fruitcentre, PCiTAL, Park of Gardeny, Fruitcentre Building, 25003 Lleida, Spain; \\ carolina.font@irta.cat (C.F.iF.); gemma.reig@irta.cat (G.R.) \\ 3 Department of Quality and Agricultural Analyses, Agro-environmental Laboratory, Government of Aragon, \\ Apdo. 727, 50080 Zaragoza, Spain; jbetran@aragon.es \\ * Correspondence: mmoreno@eead.csic.es; Tel.: +34-976-716136 \\ + These authors contributed equally to this work.
}

Received: 24 June 2020; Accepted: 1 August 2020; Published: 8 August 2020

\begin{abstract}
Since there are many different factors which affect peach orchard profitability, it is necessary to conduct long-term studies to find the best scion/rootstock combination within the constraints imposed by local climate and economic conditions. The influence of six peach-almond hybrids ("Adafuel", "Adarcias", Garnem", "GF 677", "PADAC 9902-01" and "Rootpac 70"); one P. persica $\times$ P. davidiana hybrid: "Cadaman"; five hexaploid plums ("Adesoto 101", "PM 44 AD", "PM 105 AD", "PM 150 AD", and "Penta"); three plum $\times$ peach-almond hybrids ("PADAC 04-01", "PADAC 04-03" and "PADAC 99-05"), and one plum x almond hybrid ("Rootpac R") on agronomic, basic fruit quality parameters, and flower and leaf mineral nutrients of the "Big Top" nectarine was tested. The highest vigor was induced by "Adafuel", while the lowest vigor was exhibited by "PM 105 AD", although the latter did not differ from the rest of the rootstocks. Yield efficiency was higher for "Adesoto 101" and lower for "Adafuel". Regarding the soluble solids content (SSC), "PADAC 04-01" rootstock induced the highest average content, although it did not differ from "Adarcias", "Adesoto 101", "PADAC 99-05", "PM 105 AD", and "Rootpac R". In addition, significant effect of rootstock was found on the flower and leaf mineral analysis traits evaluated. The medium ("Adarcias", "Adesoto 101", "PM 105 AD") to high vigorous plum based hybrid rootstocks ("PADAC 04-01", "PADAC 99-05" and "Rootpac R") showed the tendency to induce a better fruit quality, based on higher concentration of SSC, and other yield attributes, demonstrating their commercial interest as new rootstocks for peaches. Considering its overall performance, "PADAC 04-01" appears as a new promising rootstock alternative to peach-almond hybrids on heavy and calcareous textured soils.
\end{abstract}

Keywords: almond; fruit quality; mineral nutrients; plum; SSC; vigor

\section{Introduction}

In fruit production worldwide, cultivar is a key factor determining productivity, fruit quality and economic value [1]. The continuously release of new peach (Prunus persica) cultivars by breeders from around the world, together with the consistent improvement on orchard management strategies by growers and the commercial interest of peach production for fruit fresh consumption, allowed Spain to be the first world peach exporter and currently the largest producer in the European Union $[2,3]$. This commodity is mainly produced in the Ebro Valley (Mediterranean basin), where most of the 
peach orchards located at the Ebro river basin grow on calcareous and alkaline soils [4]. Nowadays, rising temperatures and extreme weather events are increasingly affecting the Mediterranean basin, an area classified as extremely vulnerable to global warming [5]. Currently, summers in this area reach $35-40{ }^{\circ} \mathrm{C}$ during the day and does not cool at night, with one or two heat waves in the last five years. Such events are expected to get worse by the end of the century [6] and thereby multiple agricultural ecosystems are threatened by global warming.

Peach tree is a composite of two parts: rootstock and cultivar. Therefore, the continuous improvement of cultivars must be linked with rootstocks that confer the best characteristics to them. For this reason, rootstock breeding programs are very active in the release of new Prunus rootstocks. Currently, Prunus rootstocks have their origins in private breeding programs such as "Rootpac" series from Agromillora Iberia S.L and "Cornestone" from Burchell Nursery Inc., in Research Institutes such as "Penta" and "Tetra" from Centro di Ricerca per la Frutticoltura (CRF), "G $\times$ N" series from Centro de Investigación y Tecnología Agroalimentaria de Aragón (CITA), "Adesoto 101", "Adafuel" and "Adarcias" from Estación Experimental de Aula Dei (EEAD-CSIC), "Cadaman" and "GF 677" from Institute National de la Recherche Agronomique (INRA), and "Krymsk" series from Krymsk Experimental Breeding Station, and in Universities such as "Controller"TM series from University of Davis [7,8].

In general, Prunus rootstocks breeding programs aim to improve peach adaptability to the different soil types and climatic conditions [9-11], improve fruit quality performance [12-15], add tolerance/resistance to different biotic and abiotic stresses [16,17], improve cultivar-rootstock graft compatibility $[18,19]$, and induce precocity improving productivity with the adoption of different size-controlling rootstocks, especially those with medium-low vigor allowing high density systems and bidimensional canopies [20,21].

Since there are many different factors which affect peach orchard profitability, it is necessary to conduct long-term studies to find the best scion/rootstock combination, within the constraints imposed by local climate and economic conditions. The rootstock effect on agronomic and fruit quality traits with different commercial cultivars is well known for the most commonly used rootstocks in the peach industry [22-24]. However, as far as we concern there are no Prunus rootstocks field studies evaluating agronomic, fruit quality traits and flower and leaf mineral nutrition under hot climate in heavy textured and calcareous soil comparing different Prunus rootstocks (recently released and not yet released) using "Cadaman" and "GF 677" as controls. Thus, this study aims to investigate the effectiveness of sixteenth rootstocks using the cultivar "Big Top" on productive parameters, fruit quality, and flower and leaf mineral status. The "Big Top" nectarine cultivar was selected in this experiment because of its commercial importance in European peach industry. It is a slow-softening rate cultivar and very appreciated for its early coloration resulting in greatly colored fruit, optimum fruit size, high sweetness, juiciness and flavor $[15,25]$.

\section{Materials and Methods}

\subsection{Plant Material}

Six peach-almond hybrids (P. amygdalo-persica: "Adafuel”, "Adarcias", “Garnem", "GF 677", "PADAC 9902-01" and "Rootpac 70"); one P. persica $\times$ P. davidiana hybrid: "Cadaman"; five hexaploid plums (P. insititia: "Adesoto 101", “PM 44 AD", "PM 105 AD", "PM 150 AD”, and P. domestica: "Penta"); three diploid plum $x$ peach-almond hybrids (P. cerasifera $\times$ P. amygdalo-persica: "PADAC 04-01", "PADAC 04-03" and "PADAC 99-05"); and one plum $x$ almond hybrid (P. cerasifera $\times$ P. amygdalus: "Rootpac R") (Table 1) were T-budded with the "Big Top" nectarine cultivar in the summer of 2007. "GF 677" and "Cadaman" rootstocks were used in the trial as references [11], since both accounted 71\% of the total rootstocks used in Spain, in particular 50\% and 21\% respectively [11]. 
Table 1. List of evaluated rootstocks in this study, description and origin.

\begin{tabular}{|c|c|c|c|c|c|c|c|}
\hline Rootstock & Species & Type & $\begin{array}{c}\text { Genetic } \\
\text { Background }\end{array}$ & Origin $^{a}$ & Calcareous Soil $\mathbf{T}^{\mathbf{b}}$ & Waterlogging $\mathrm{T}^{\mathrm{b}}$ & References \\
\hline "Adafuel ${ }^{\circledR "}$ & P. amygdalus $\times$ P. persica & Vigorous & Open-pollinated & CSIC, Spain & HT & $S$ & Moreno et al. [26] \\
\hline "Adarcias ${ }^{\circledR "}$ & P. amygdalus $\times$ P. persica & Semi-vigorous & Open-pollinated & CSIC, Spain & $\mathrm{T}$ & MT & Moreno et al. [26] \\
\hline “Adesoto ${ }^{\circledR} 101 "$ & P. insititia & Semi-vigorous & Open-pollinated & CSIC, Spain & HT & HT & Moreno et al. [27] \\
\hline “Cadaman ${ }^{\circledR ”}$ & P. persica $\times P$. davidiana & Vigorous & Controlled cross & INRA, France & $\mathrm{T}$ & MT & $\begin{array}{c}\text { Edin and Garcin } \\
\text { [28] }\end{array}$ \\
\hline “Garnem ${ }^{\circledR ”}$ & P. amygdalus $\times$ P. persica & Vigorous & Controlled cross & CITA, Spain & $\mathrm{HT}$ & S & Felipe [29] \\
\hline “GF 677” & $P$. amygdalus $\times P$. persica & Vigorous & Open-pollinated & INRA, France & $\mathrm{HT}$ & S & $\begin{array}{l}\text { Bernhard and } \\
\text { Grasselly [30] }\end{array}$ \\
\hline “PADAC 04-01" & $\begin{array}{c}\text { P. cerasifera } \times(\text { P. amygdalus } \\
\times \text { P. persica })\end{array}$ & Vigorous & Controlled cross & CSIC, Spain & HT & HT & Moreno [9] \\
\hline “PADAC 04-03" & $\begin{array}{c}\text { P. cerasifera } \times(\text { P. amygdalus } \\
\times P \text {. persica })\end{array}$ & Vigorous & Controlled cross & CSIC, Spain & HT & $\mathrm{HT}$ & Moreno [9] \\
\hline “PADAC 99-05” & $\begin{array}{c}\text { P. cerasifera } \times(\text { P. amygdalus } \\
\times \text { P. persica })\end{array}$ & Vigorous & Controlled cross & CSIC, Spain & HT & HT & Moreno [9] \\
\hline “PADAC 9902-01" & $\begin{array}{l}(\text { P. amygdalus } \times \text { P. persica }) \\
\times(P . \text { persica } \times \text { P. davidiana })\end{array}$ & Vigorous & Controlled cross & CSIC, Spain & $\mathrm{HT}$ & HT & Moreno [9] \\
\hline “Penta" & P. domestica & Semi-vigorous & Open-pollinated & CRF, Italy & $\mathrm{T}$ & $\mathrm{T}$ & $\begin{array}{c}\text { Nicotra and Moser } \\
{[31]}\end{array}$ \\
\hline “PM 44 AD” & P. insititia & Semi-vigorous & Open-pollinated & CSIC, Spain & $\mathrm{T}$ & $\mathrm{T}$ & Moreno [9] \\
\hline “PM 105 AD” & P. insititia & Semi-vigorous & Open-pollinated & CSIC, Spain & $\mathrm{T}$ & $\mathrm{T}$ & Moreno [9] \\
\hline “PM 150 AD” & P. insititia & Semi-vigorous & Open-pollinated & CSIC, Spain & $\mathrm{T}$ & $\mathrm{T}$ & Moreno [9] \\
\hline “Rootpac ${ }^{\circledR} 70 ”$ & $\begin{array}{c}\text { P. persica } \times(P . \text { amygdalus } \times \\
P . \text { persica })\end{array}$ & Vigorous & Controlled cross & AI, Spain & HT & MT & Jiménez et al. [20] \\
\hline “Rootpac ${ }^{\circledR} \mathrm{R}^{\prime}$ & P. cerasifera $\times P$. amygdalus & Vigorous & Controlled cross & AI, Spain & $\mathrm{HT}$ & HT & Pinochet [32] \\
\hline
\end{tabular}


The trial was located in the Ebro Valley (North Eastern Spain; lat. $41^{\circ} 43^{\prime} 42.7^{\prime \prime} \mathrm{N}$, long. $0^{\circ} 48^{\prime} 44.1^{\prime \prime} \mathrm{W}$ ) on a Xerosol calcic soil [35]. Similarly, the field plot was classified as having a silty-clay-sandy texture (Table 2) following the USDA soil textural classification system. In this area (cold-semiarid Mediterranean climate), the average annual precipitation amounts to $345 \mathrm{~mm}$, the diurnal temperature variation amounts to $13.3{ }^{\circ} \mathrm{C}$, and the reference evapotranspiration ranges from $997 \mathrm{~mm}$ to $1140 \mathrm{~mm}$ [35]. Cultural management practices such as fertilization, winter pruning, and spring thinning, were conducted as in a commercial orchard. Hand-thinning was carried out at 40 days after full bloom (DAFB) to maintain a minimum spacing between fruits (approximately $20 \mathrm{~cm}$ ). Foliar pesticides and insecticides were applied as necessary, following industry standards. The experiment was established in a randomized block design with five replicates for each rootstock. Guard rows were used to avoid edge effects. Trial was established in the field during the winter of 2008-2009. Trees were trained to a low density open-vase system $(5 \mathrm{~m} \times 4 \mathrm{~m})$, a very common planting system 10 years ago in peach orchards, when the trial was set up. The trial was level-basin irrigated with a dose of $1000 \mathrm{~m}^{3} \mathrm{ha}^{-1}$ every twelve days during the summer, for the first three years until 2012. Later, drip irrigation was established to follow standard irrigation management of peach orchards. The criteria were following modern procedures by fruit growers and having new irrigation facilities recently stablished at the experimental field we adopted this new procedure, with a maximum dose of $250 \mathrm{~m}^{3} \mathrm{ha}^{-1}$ week ${ }^{-1}$ during the months with higher water requirements (June and July).

Table 2. Soil analysis description.

\begin{tabular}{|c|c|c|c|c|c|c|c|c|c|c|}
\hline $\begin{array}{l}\text { Depth } \\
\text { (cm) }\end{array}$ & Texture & $\begin{array}{c}\text { E.C. } \\
(1: 5) \\
(\mathrm{dS} / \mathrm{m})\end{array}$ & $\mathrm{pH}$ & $\begin{array}{c}\text { Organic } \\
\text { Matter a } \\
(\%)\end{array}$ & $\begin{array}{c}P^{b} \\
(p p m)\end{array}$ & $\begin{array}{c}\mathrm{K}^{\mathrm{c}} \\
(\mathrm{ppm})\end{array}$ & $\begin{array}{l}\mathrm{NO}_{3} \mathrm{~d} \\
(\mathrm{ppm})\end{array}$ & $\begin{array}{c}\mathrm{Mg}^{\mathrm{c}} \\
(\mathrm{mg} / \mathrm{kg})\end{array}$ & $\begin{array}{c}\mathrm{CaCO}_{3} \mathrm{e} \\
(\%)\end{array}$ & $\begin{array}{c}\text { Active } \\
\text { Limestone } \\
\text { (\%) }\end{array}$ \\
\hline $0-30$ & Silty-Clay-Sandy & 0.30 & 8.3 & 3.21 & 31 & 388 & 14 & 296 & 32 & 7.00 \\
\hline $30-60$ & Silty-Clay-Sandy & 0.30 & 8.4 & 1.76 & 10 & 168 & 6 & 208 & 32 & 6.78 \\
\hline $60-90$ & Silty-Clay-Sandy & 0.40 & 8.4 & 0.98 & 4 & 148 & 2 & 192 & 33 & 6.38 \\
\hline
\end{tabular}

${ }^{\mathrm{a}}$ Organic matter was measured using Walkley and Black [36] method. ${ }^{\mathrm{b}}$ Assimilable phosphorus was measured using Olsen and Watanabe [37] method. ${ }^{c}$ Potassium and magnesium were extracted by ammonium acetate $1 \mathrm{~N}$ at $\mathrm{pH}=7$ and analyzed by atomic absorption spectrophotometry. ${ }^{\mathrm{d}}$ Nitrogen was measured using Kjeldahl analysis (Gerhardt Vapodest). ${ }^{\mathrm{e}}$ Carbonates were measured using Bernard calcimeter method [38]. ${ }^{\mathrm{f}}$ Active limestone was determined by Nijelson method.

\subsection{Weather Conditions}

Meteorological data from 2013-2017: the average daily temperature (Tavr, ${ }^{\circ} \mathrm{C}$ ), the average minimum daily temperature $\left(\operatorname{Tmin},{ }^{\circ} \mathrm{C}\right)$, and the average maximum daily temperature $\left(\operatorname{Tmax},{ }^{\circ} \mathrm{C}\right)$ as well as rainfall $(\mathrm{mm})$ and solar radiation $\left(\mathrm{Sr}, \mathrm{W} \mathrm{m}^{-2}\right.$ ) from blooming (first fortnight of March) until harvest date (first fortnight of July), which covers each fruit growing period, were downloaded from the meteorological automated station located very close $(\approx 100 \mathrm{~m})$ to the field trial.

\subsection{Tree Mortality and Field Determinations}

Tree health and survival were monitored throughout the trial. Dead trees were recorded each year, from 2010 until 2017, when growth measurements were taken in December and tree mortality was expressed as a percentage. It should be noted that for rootstock "PM 150 AD", less than three replicates were available in the last year of study (2017). Consequently, it was excluded of the statistical analysis.

The trunk cross-sectional area (TCSA, $\mathrm{cm}^{2}$ ) and yield ( $\mathrm{kg} /$ tree) were determined from 2010 until 2017. Trunk circumferences were measured during the dormant season (December) at $20 \mathrm{~cm}$ above the graft union. At harvest, all fruits from each tree were weighed to determine total yield per tree ( $\mathrm{kg} /$ tree). Cumulative yield and cumulative yield efficiency (cumulative yield in kilograms per tree per final TCSA) of each scion/rootstock combination were computed in 2017. 


\subsection{Fruit Quality Determinations}

During harvest, 20 mature fruits (flesh firmness in the range of 40-50 $\mathrm{N}$ and fruit color $\geq 80 \%$ of fruit surface) of each tree were randomly selected each season for the period of 2013 to 2017. Sampled fruits were randomly selected at commercial harvest by a single person to keep consistency of maturity grade. Fruits were individually weighted and average fruit weight (AFW) was determined. Soluble solids content (SSC) of fruit juice was measured with a digital refractometer (Atago PR-101, Tokyo, Japan) and was expressed as ${ }^{\circ}$ Brix. To analyze titratable acidity (TA), $5 \mathrm{~g}$ of homogenized samples were diluted with $50 \mathrm{~g}$ of distilled water and microtitrated with $0.1 \mathrm{~N} \mathrm{NaOH}$. The results were expressed as g malic acid/100 g FW. Ripening index (RI) was calculated based on the SSC/TA ratio. Flesh firmness (Newtons) was measured using a penetrometer (Model FT-327) on two paired sides of each fruit, by removing one mm thick disk of skin. From 2013 to 2016, color parameters were determined and values of $L^{*}$ (brightness or lightness), $a^{*}\left(-a^{*}\right.$, greenness, $+a^{*}$, redness), $b^{*}\left(-b^{*}\right.$, blueness, $+b^{*}$, yellowness), $\mathrm{C}^{*}$ (chroma) and h (hue angle) were measured using a colorimeter (Chroma Meter, CR-400 Konica Minolta) [39].

\subsection{Flower and Leaf Mineral Analysis}

Flower and leaf mineral element concentrations were determined in 2017, i.e., in year nine after planting, using healthy trees for sampling. One hundred whole fully opened flowers per tree (including petals, sepals, reproductive parts, bracts and peduncles) were taken at full bloom (in early March). Flowers were sampled from the central part of the shoots around the tree crown. These fresh flowers were then put into an air forced stove $\left(60{ }^{\circ} \mathrm{C}\right)$ and $24 \mathrm{~h}$ later ground to a fine powder (in a conventional coffee mill). Leaf sampling was carried out at 120 days after blooming (DAFB), as described in other Prunus rootstocks studies $[33,40]$. It was approximately the harvest time period of "Big Top" nectarine in our climate conditions.

The mineral element composition of the dried tissue was determined using the method of C.I.I. et al. [41], as previously reported by Mestre et al. [33]. Total $\mathrm{N}$ was determined by Dumas method (LECO Inc. FP-528, Madrid, Spain); the macroelement $P$ was analyzed spectrophotometrically by the phospho-vanadate colorimetric method (ThermoSpectronic Helios $\beta$ ); and the macroelements Ca, K, $\mathrm{Mg}$, and the microelements $\mathrm{Cu}, \mathrm{Fe}, \mathrm{Mn}$ and $\mathrm{Zn}$ by atomic emission spectroscopy (ICP, Horiba-Jobin Yvon, Active-M, Longjumeau, France).

The DOP index (deviation from optimum percentage) on leaves was estimated for the diagnosis of the nutritive status of the trees [42]. The DOP index was calculated from the leaf analysis by the following mathematical expression:

$$
D O P=\left[\frac{C-C_{r e f}}{C_{r e f}}\right] \times 100
$$

where $C$ is the nutrient concentration in the sample to be studied and $C_{\text {ref }}$ is the nutrient concentration considered as optimum, both values given on a dry matter basis. The $C_{r e f}$ has been taken from optimum values proposed by different authors $[43,44]$. The $\Sigma D O P$ is obtained by adding the values of DOP indices irrespective of sign. The larger was the $\Sigma$ DOP the greater was the intensity of imbalances among nutrients.

\subsection{Data Analysis}

All variables evaluated followed normal distribution based on Shapiro-Wilk W Test. Data were subjected to a two-way ANOVA analysis in order to examine year $(\mathrm{Y})$, rootstock $(\mathrm{R})$, and $\mathrm{Y} \times \mathrm{R}$ interaction. The total variability of each parameter was estimated using the total sum squares of two-way ANOVA results. Additionally, the variability expressed as percentage of the total sum of squares for year, rootstock, and the interaction between both was calculated. When the F test was significant, means were separated by the HSD Tukey test $(p \leq 0.05)$. Pearson correlation analyses were 
performed to study correlations among traits evaluated. The hierarchical agglomerative cluster was done to represent similarity between rootstocks and variables evaluated. All statistics analysis was designed using JMP (Version 14.2; SAS Institute Inc., Cary, NC, USA).

\section{Results and Discussion}

\subsection{Weather Conditions}

The average daily temperature (Tavr) and the average maximum daily temperature (Tmax) were higher in the fruit growing season of 2017, especially when compared to 2013 and 2016 seasons (Table 3). Moreover, year 2017 had less rainfall accumulated compared to the rest of the four years. Years 2014 and 2015 also stood out for having high Tavr and Tmax, whereas 2013 for being the year with more rain accumulated during the fruit growing period.

Table 3. Average daily temperature (Tavr), average minimum daily temperature (Tmin), average maximum daily temperature (Tmax) and solar radiation $(\mathrm{Sr})$ and cumulative rainfall $(\mathrm{mm})$ during the fruit growing season (from full blooming until harvest) from 2013 to 2017.

\begin{tabular}{cccccc}
\hline Year & $\operatorname{Tavr}\left({ }^{\circ} \mathbf{C}\right)$ & $\operatorname{Tmin}\left({ }^{\circ} \mathbf{C}\right)$ & $\operatorname{Tmax}\left({ }^{\circ} \mathbf{C}\right)$ & $\operatorname{Sr}\left(\mathbf{W ~ m}^{-2}\right)$ & Rainfall * $(\mathbf{m m})$ \\
\hline 2013 & $14.5 \mathrm{c}$ & $8.1 \mathrm{~b}$ & $21.1 \mathrm{c}$ & $268.2 \mathrm{~ns}$ & 151.0 \\
2014 & $17.0 \mathrm{ab}$ & $9.9 \mathrm{a}$ & $24.3 \mathrm{ab}$ & 272.1 & 105.0 \\
2015 & $17.1 \mathrm{ab}$ & $10.1 \mathrm{a}$ & $25.0 \mathrm{ab}$ & 257.3 & 108.6 \\
2016 & $15.9 \mathrm{bc}$ & $8.9 \mathrm{ab}$ & $22.9 \mathrm{bc}$ & 244.8 & 115.0 \\
2017 & $17.8 \mathrm{a}$ & $9.4 \mathrm{ab}$ & $26.0 \mathrm{a}$ & 273.0 & 91.0 \\
\hline
\end{tabular}

Means followed by the different letter in each column are significantly different at $p \leq 0.05$ according to HSD Tukey Test. ns, not significant. * Not evaluated statistically. Rainfall is an accumulated value.

Over the five years of weather data presented in this study, a general trend of increasing temperatures is observed, except for 2016. Nowadays, rising temperatures and extreme weather events are increasingly affecting the Mediterranean basin, an area classified as extremely vulnerable to global warming [5]. High temperatures together with excessive radiation negatively affect peach production by compromising key developmental stages of the fruit as well as affecting the final fruit quality and storability.

\subsection{Tree Mortality}

At the ninth year after budding, growing conditions generated varying levels of tree mortality, the highest (100\%) with the peach-almond hybrid "Garnem", and the hexaploid plums "PM 44 AD" and "Penta" (Figure 1). Consequently, they were excluded of the trial due to their high tree mortality experienced during the first years after planting. In contrast, the peach-almond hybrids "Adarcias" and "Rootpac 70", as well as the interspecific plum based rootstocks "PADAC 04-01" and "Rootpac $\mathrm{R}^{\prime}$ survived well. Mestre et al. [33] also reported the poor and good adaptation of "Garnem" and "Rootpac $\mathrm{R}$ " respectively, growing under root asphyxia and heavy soil conditions. The peach-almond hybrids "GF 677" and "PADAC 9902-01", the hexaploid plums "PM 105 AD" and "PM 150 AD", and the peach-plum hybrid "PADAC 99-05", experienced also a high tree mortality mostly during the first growing years (40\% of dead trees), in contrast with results previously reported for "GF 677" [40,45]. Nevertheless, "Adesoto 101" experienced a $20 \%$ mortality rate, in agreement with results obtained by other authors [20,33]. In this trial, tree mortality could be attributed to the sensitivity to root asphyxia caused by waterlogging conditions [33] or susceptibility to pathogens as Phytophtora spp. [40,46] or other pathogens [47]. 




Figure 1. Tree mortality rate (\%) from the second (2010) to the ninth (2017) year after planting. No trees were lost in the period 2013-2015.

Short-waterlogging conditions are very common in clay-loam textured soils [48], the most frequent soils type in the Ebro Valley and the Murcia region, the largest producer areas in Spain. Since this country is the first peach producer in Europe, that type of soils is very common in the most important peach growing areas. Our field plot was classified as having a silty-clay-sandy texture. This texture can induce waterlogging problems and root asphyxia to sensitive rootstocks as peach seedlings and peach-almond hybrids [49]. Moreover, heavy textured soils facilitate flooding with the occurrence of intense rains, commonly concentrated in very short periods of the summer in the Mediterranean area [48]. Typical symptoms observed included an initial leaf wilting and defoliation followed by dead of twigs, and further of larger branches, and finally tree declined and died. Ziegler et al. [49] suggested that in fruit trees (especially in peach, as one of the most susceptible Prunus species to root anoxia in flooded soils) flooding stress can affect significantly plant survival and growth. Tolerance to root anoxia is determined by rootstock characteristics, and the differences in the responses to flooding should be considered in production settings where it is not possible to properly control irrigation to prevent short periods of flooding or in soils that do not drain irrigation or rain water quickly $[48,49]$.

\subsection{Production and Fruit Quality}

As depicted in Table 4, the analysis of variance (ANOVA, $p \leq 0.05$ ) showed that year and rootstock, but not their interaction, significantly affected tree vigor (TCSA) and yield. However, fruit weight (FW) was only significantly affected by year, although the main source of variability was the interaction year $\times$ rootstock.

Rootstock was the main source of variability for tree vigor (TCSA) (Table 4). The highest vigor was induced by the peach-almond hybrid "Adafuel" followed by "GF 677" (Table 5). However, the last one did not differ statistically from the rest of the rootstocks evaluated, in agreement with previous studies [11,33]. Vigorous rootstocks could appear suitable for peach production under replanting conditions or in poor and calcareous soils that might otherwise not be favorable for growing peach [26]. Massai and Loreti [50] reported also that the most vigorous rootstocks appear to offer the best guarantees for the realization of efficient and uniform plantings in replant soils. Therefore, "Adafuel" and "GF 677" could be great rootstocks candidate for this type of soils. In addition, it is worth mentioning that "PADAC 04-03" and "Rootpac 70" had similar vigor in two soil conditions, our silty-clay-sandy and calcareous soil and the loamy and calcareous soil, as reported by Reig et al. [11]. The lowest TCSA

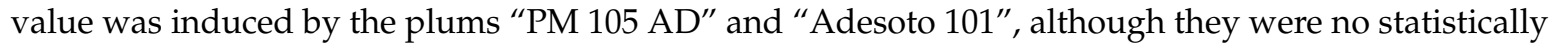


different from the rest of the rootstocks but "Adafuel". Reig et al. [11] also reported a medium vigor of these two plum rootstocks. Therefore, plums may be suitable for reducing excessive growth of peach cultivars growing in fertile soils or to increase planting density [33].

Table 4. Statistical significance of year, rootstock, and their interaction of rootstock on tree performance and fruit quality of "Big Top" budded on 12 rootstocks.

\begin{tabular}{|c|c|c|c|c|c|c|c|}
\hline \multirow{2}{*}{ Trait } & \multirow{2}{*}{ Units/Description } & \multicolumn{2}{|c|}{ Variance Analysis } & \multicolumn{4}{|c|}{ Variability $^{a}(\%)$} \\
\hline & & Year (Y) & Rootstock (R) & $\mathbf{Y} \times \mathbf{R}$ & Year $(Y)$ & Rootstock (R) & $\mathbf{Y} \times \mathbf{R}$ \\
\hline TCSA & $\mathrm{cm}^{2}$ & $* * *$ & $* * *$ & ns & 34.9 & 59.7 & 5.4 \\
\hline Yield & $\mathrm{Kg} /$ tree & $* * *$ & $* *$ & ns & 75.8 & 12.0 & 12.2 \\
\hline Average Fruit weight & grams & $*$ & ns & ns & 23.5 & 31.4 & 45.1 \\
\hline Soluble solid content (SSC) & ${ }^{\mathrm{o}}$ Brix & $* * *$ & $* * *$ & ns & 56.1 & 28.0 & 15.9 \\
\hline Titratable acidity (TA) & $\mathrm{g}$ malic acid per $100 \mathrm{~g}$ FW & $* * *$ & $* * *$ & $* * *$ & 36.6 & 25.2 & 38.3 \\
\hline Flesh firmness & Newtons & $* * *$ & ns & ns & 85.4 & 4.9 & 9.7 \\
\hline $\begin{array}{c}\text { Brightness or Lightness } \\
\text { angle (L) }\end{array}$ & Color parameter & $* * *$ & * & ns & 93.5 & 2.4 & 4.0 \\
\hline Greenness or Redness $\left(a^{*}\right)$ & Color parameter & $* * *$ & * & * & 97.6 & 0.8 & 1.6 \\
\hline Blueness or Yellowness $\left(b^{*}\right)$ & Color parameter & $* * *$ & $* *$ & ns & 97.7 & 1.0 & 1.3 \\
\hline Chroma $\left(C^{*}\right)$ & Color parameter & $* * *$ & $* *$ & ns & 95.1 & 2.1 & 2.9 \\
\hline Hue angle (h) & Color parameter & $* * *$ & $* *$ & ns & 85.7 & 6.6 & 7.7 \\
\hline
\end{tabular}

ns, not significant; ${ }^{*} p \leq 0.05 ;{ }^{* *} p \leq 0.01 ;{ }^{* * *} p \leq 0.001$. ${ }^{\text {a }}$ Data were evaluated by two-way variance analysis (ANOVA).

Table 5. Effect of rootstock on horticultural traits in the ninth year (2017) after planting.

\begin{tabular}{|c|c|c|c|c|c|}
\hline Rootstock & Final TCSA $\left(\mathrm{cm}^{2}\right)$ & Average Yield (kg/tree) & CY (kg/tree) & CYE $\left(\mathrm{kg} / \mathrm{cm}^{2}\right)$ & Average $\mathrm{FW}^{\mathrm{a}}$ (g) \\
\hline "Adafuel" & $444.9 \mathrm{a}$ & $39.5 \mathrm{a}$ & $182.1 \mathrm{~ns}$ & $0.42 \mathrm{~b}$ & $171.1 \mathrm{~ns}$ \\
\hline "Adarcias" & $187.4 \mathrm{~b}$ & $27.0 \mathrm{abc}$ & 123.1 & $0.68 \mathrm{ab}$ & 175.0 \\
\hline "Adesoto 101" & $157.9 \mathrm{~b}$ & $21.7 \mathrm{c}$ & 123.7 & $0.86 \mathrm{a}$ & 177.5 \\
\hline “Cadaman" & $274.3 \mathrm{~b}$ & $33.2 \mathrm{abc}$ & 170.7 & $0.61 \mathrm{ab}$ & 197.0 \\
\hline “GF 677” & $303.3 \mathrm{ab}$ & $34.1 \mathrm{abc}$ & 176.4 & $0.62 \mathrm{ab}$ & 176.3 \\
\hline “PADAC 04-01" & $285.5 \mathrm{~b}$ & $33.3 \mathrm{abc}$ & 165.9 & $0.59 \mathrm{ab}$ & 173.0 \\
\hline "PADAC 04-03" & $259.9 \mathrm{~b}$ & $27.2 \mathrm{abc}$ & 137.1 & $0.52 \mathrm{ab}$ & 180.4 \\
\hline "PADAC 99-05" & $267.3 \mathrm{~b}$ & $30.1 \mathrm{abc}$ & 160.4 & $0.61 \mathrm{ab}$ & 183.6 \\
\hline “PADAC 9902-01" & $279.7 \mathrm{~b}$ & $36.1 \mathrm{ab}$ & 189.9 & $0.69 \mathrm{ab}$ & 183.2 \\
\hline "PM 105 AD" $^{\prime}$ & $139.8 \mathrm{~b}$ & $21.0 \mathrm{c}$ & 105.4 & $0.82 \mathrm{ab}$ & 169.3 \\
\hline “Rootpac 70" & $243.9 \mathrm{~b}$ & $30.0 \mathrm{abc}$ & 141.8 & $0.57 \mathrm{ab}$ & 182.1 \\
\hline “Rootpac R" & $247.1 \mathrm{~b}$ & $28.9 \mathrm{abc}$ & 141.4 & $0.59 \mathrm{ab}$ & 169.2 \\
\hline
\end{tabular}

Means followed by different letters in each column are significantly different at $p \leq 0.05$ according to HSD Tukey Test. ns, not significant. Abbreviations: CY, cumulative yield; CYE, cumulative yield efficiency; TCSA, trunk cross sectional area; FW, average fruit weight. ${ }^{\text {a }}$ Data obtained from a subsample of 20 fruits each harvest.

Regarding yield $\left(\mathrm{kg} \mathrm{tree}^{-1}\right)$, the highest variability was attributed to the year, as shown in Table 4 . Yields were reduced by spring frosts in 2016. All rootstocks produced fruits from the third year after planting (2011) (Figure 2), showing more clear differences among rootstocks at the sixth year after planting (2014). Thus, at the end of the trial (2017), the average yield was significantly affected by rootstock. The highest average yield was induced by the vigorous peach-almond hybrid "Adafuel", as shown in other studies [45], although it did not differ statistically from the rest of the rootstocks except for plums "PM 105 AD" and "Adesoto 101" (Table 5). In this study, because spacing was the same for all rootstocks, higher yields per tree or per hectare are related with rootstock vigor and greater canopy volume. Recalculating the planting distance of each rootstock based on its induced vigor is desirable to compare yields. Also, "GF 677" will be considered as reference rootstock [11]. Hence, comparing them in terms of cumulative yield efficiency $\left(\mathrm{kg} \mathrm{cm}^{-2}\right)$, the highest value was shown for "Adesoto 101", although differences were not significant with the other rootstocks evaluated, except for "Adafuel" which induced the lowest value (Table 5). Higher vigorous rootstocks, in general, induce lowest yield efficiency (YE) [24,51]. In our study, the tendency of the plum "Adesoto 101" to show higher YE is probably due to its lower vigor and the resulting good level of yield, as previously reported with other peach cultivars $[17,22,25]$. On the contrary, the tendency of the peach-almond hybrid "Adafuel" to show low YE is probably due to its higher vigor [45]. 


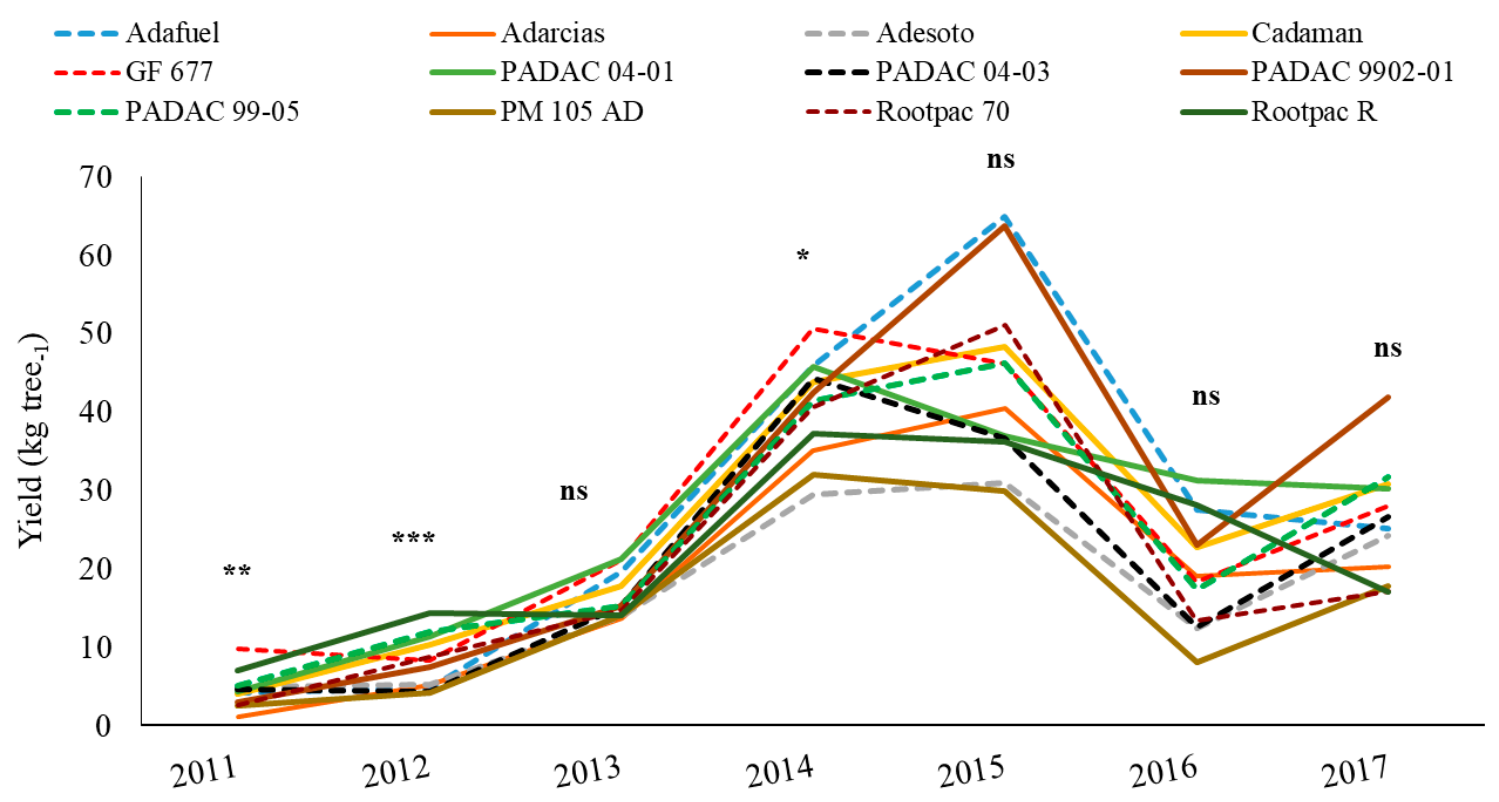

Figure 2. Annual yields $\left(\mathrm{kg}_{\mathrm{g}}\right.$ tree $\left.{ }^{-1}\right)$ of "Big Top" nectarine cultivar budded on 12 Prunus rootstocks. The significance is designated by asterisks as follows: ${ }^{*}$, statistically significant differences at $p$-value $<0.05 ; * *$, statistically significant differences at $p$ value $<0.01 ; * *$, statistically significant differences at $p$-value $<0.001 ;$ ns, not significant.

\subsection{Fruit Quality Determinations}

The ANOVA analysis reported a significant effect of the year $(\mathrm{Y})$ and rootstock $(\mathrm{R})$ for all traits studied, except for firmness (FF) and fruit weight (FW) which were not affected by rootstock (Table 4). The year $\mathrm{x}$ rootstock interaction was not significant for most of the traits, hence highlighting that most rootstocks responded in a similar way to changes in the weather conditions [15], except for titratable acidity (TA) and $\mathrm{a}^{*}$ parameters, indicating a different rootstock performance in relation to the climatic conditions. However, except for TA, which had similar variability caused by year and the interaction year $\times$ rootstock, the variability caused by the rest of the traits evaluated was mostly caused by the year.

\subsubsection{Effect of Year on Fruit Quality Traits}

When selecting the best cultivar/rootstock combination, it is crucial to evaluate the overall variability for most of fruit quality traits. In addition, it is important to understand which fraction of this variability is explained by the year, the rootstock, and/or their interaction. It is also important to evaluate which climate factor (temperature, precipitation, and solar radiation) is dominant in explaining the year-to-year variability [15]. In this work, all traits were not correlated with any of the weather variables evaluated, except for SSC and TA, leading to the thought that other factors differing between years play a critical role in them, such as tree vigor or crop differences observed during the five years of study, as previously reported [52].

The Tavr was highly and positively correlated with SSC $(r=0.99, p \leq 0.01)$ and the Tmax was highly and negatively correlated with TA $(r=-0.91, p \leq 0.05)$, thereby partly explaining the influence of the year on these two traits. Font i Forcada et al. [14] indicated that sugars profile in fruits was positively correlated with temperature factors, showing that environmental variables such as temperature and/or solar radiation influence the tree-growing environment. In contrast, Iglesias et al. [15] reported a negative correlation between SSC and growing degree days (the difference between the daily mean temperature and a base temperature of $10{ }^{\circ} \mathrm{C}$ from full bloom date to harvest date). The low air temperature could play a role in an overall reduction in fruit size and sugar concentration [53]. Font i Forcada et al. [14] reported that organic acids profile in fruits was negatively correlated with temperature factors for three years of evaluation, as happens in the present study for TA and five 
years. In contrast to our results, Iglesias et al. [15] reported that malic acid was not affected by weather variables on "Big Top" budded on 20 Prunus rootstocks. However, they reflected only two years of evaluation.

\subsubsection{Effect of Rootstock on Fruit Quality Traits}

Considering differences between rootstocks for fruit quality traits, the average of the five years of study showed that the greatest SSC was recorded on the three-way plum based hybrid "PADAC 04-01", although differences were not significant compared to the peach-almond "Adarcias", the plums "Adesoto 101" and "PM 105 AD", as well as the plum based hybrids "PADAC 99-05" and "Rootpac R" (Table 6). The lowest SSC values was recorded on "Adafuel", "PADAC 9902-01", and "Rootpac 70", although differences were not significant compared to "Cadaman", "GF 677", "PADAC 04-03", and "PM 105 AD". The SSC values obtained were similar to those reported for "Big Top" in different growing conditions $[11,54]$.

Table 6. Rootstock effect on fruit quality parameters of "Big Top" fruits on twelve rootstocks during five years of study (2013-2017).

\begin{tabular}{lcccc}
\hline Rootstock & N $^{\text {a }}$ & $\begin{array}{c}\text { Average } \\
\text { SSC }\left({ }^{\circ} \text { Brix) }\right.\end{array}$ & $\begin{array}{c}\text { Average } \\
\text { TA (g Malic Acid/100 FW) }\end{array}$ & $\begin{array}{c}\text { Average } \\
\text { FF (N) }\end{array}$ \\
\hline "Adafuel" & 3 & $13.9 \mathrm{~d}$ & $0.58 \mathrm{~cd}$ & $40.4 \mathrm{~ns}$ \\
"Adarcias" & 5 & $15.7 \mathrm{abc}$ & $0.63 \mathrm{abc}$ & 42.1 \\
"Adesoto 101" & 5 & $16.0 \mathrm{ab}$ & $0.69 \mathrm{a}$ & 41.2 \\
"Cadaman" & 4 & $14.9 \mathrm{bcd}$ & $0.64 \mathrm{abc}$ & 44.2 \\
“GF 677" & 4 & $14.5 \mathrm{~cd}$ & $0.54 \mathrm{~d}$ & 44.3 \\
"PADAC 04-01" & 5 & $16.9 \mathrm{a}$ & $0.53 \mathrm{~d}$ & 41.9 \\
"PADAC 04-03" & 5 & $15.3 \mathrm{bcd}$ & $0.60 \mathrm{abc}$ & 42.7 \\
"PADAC 99-05" & 4 & $16.4 \mathrm{ab}$ & $0.64 \mathrm{abc}$ & 43.7 \\
"PADAC 9902-01" & 3 & $14.2 \mathrm{~d}$ & $0.61 \mathrm{abc}$ & 43.2 \\
"PM 105 AD" & 3 & $15.6 \mathrm{abcd}$ & $0.66 \mathrm{ab}$ & 41.5 \\
"Rootpac 70" & 4 & $14.2 \mathrm{~d}$ & $0.63 \mathrm{abc}$ & 41.8 \\
"Rootpac R" & 5 & $16.2 \mathrm{ab}$ & $0.68 \mathrm{a}$ & 46.8 \\
\hline
\end{tabular}

Means followed by different letters in each column are significantly different at $p \leq 0.05$ according to HSD Tukey Test. ns, not significant. Abbreviations: SSC, soluble solids content; TA, titratable acidity; RI, ripening index; FF, flesh firmness. ns, not significant. ${ }^{a}$ number of trees evaluated.

The plum "Adesoto 101" induced higher five-year average TA values than "Adafuel", "GF 677", "PADAC 04-01" and "PADAC 04-03" (Table 6). Orazem et al. [22] evaluated the performance of "Redhaven" peach cultivar grafted on eleven Prunus rootstocks. They observed that "Adesoto" rootstock induced higher values on FW and SSC to "Redhaven" fruits when compared to five other different plums and five peach-based rootstocks. Other different studies with "Catherina" $[17,25]$ and "Big Top" cultivars [2,14] also showed the tendency of the "Adesoto 101" rootstock to induce higher TA and specific organic acids. Despite higher acidity of fruits on this rootstock, their SSC were not affected. High sugar contents and, to a lower extent, high acid contents seem to be favourable to fruit quality as evaluated by consumers [55] and could increase the sweetness perception of the low-acid "Big Top" nectarine [14].

Fruit color is one of the most important criteria of ripening in stone fruits [56] and an important factor for marketability and consumer acceptances [57]. Indeed, consumers associate intense red color with better appearance and quality [54]. Slightly significant differences were found among rootstocks in color parameters (Table 7). Regarding $\mathrm{L}^{*}$, the lightness fruits (higher $\mathrm{L}^{*}$ values) were harvested on the plum based hybrid "PADAC 04-01" and the lower L* values (brightness fruits) on "PM 105 $\mathrm{AD}^{\prime \prime}$, although differences were not significant with the other rootstocks evaluated. For a* values, the peach-almond "Adafuel" induced fruits with the most red colored skin (higher a* value) although not significant differences were found when compared with all rootstocks except for "Rootpac R". 
It is interesting to note the tendency of "Adafuel", "Adesoto" and "PADAC 9902-01" to show more red colored fruits in 2015, when the difference between Tmax and Tmin was higher of all the years evaluated (2013 to 2016).

Table 7. Rootstock effect on the chromatic parameters of "Big Top" fruits on twelve rootstocks during four years of study (2013-2016).

\begin{tabular}{lcccccc}
\hline Rootstock & $\mathbf{n}^{\mathbf{a}}$ & $\begin{array}{c}\mathbf{L}^{*} \\
\text { (Brightness/ } \\
\text { Lightness) }\end{array}$ & $\begin{array}{c}\mathbf{a}^{*} \\
\text { (Greenness/ } \\
\text { Redness) }\end{array}$ & $\begin{array}{c}\mathbf{b}^{*} \\
\text { (Blueness/ } \\
\text { Yellowness) }\end{array}$ & $\begin{array}{c}\mathbf{C}^{*} \\
\text { (Chroma) }\end{array}$ & $\begin{array}{c}\mathbf{h} \\
\text { (Hue Angle) }\end{array}$ \\
\hline "Adafuel" & 3 & $37.3 \mathrm{ab}$ & $37.3 \mathrm{a}$ & $22.8 \mathrm{ab}$ & $35.0 \mathrm{~ns}$ & $26.9 \mathrm{ab}$ \\
"Adarcias" & 5 & $36.7 \mathrm{ab}$ & $28.3 \mathrm{ab}$ & $21.4 \mathrm{~b}$ & 32.8 & $25.1 \mathrm{~b}$ \\
"Adesoto 101" & 5 & $37.1 \mathrm{ab}$ & $27.1 \mathrm{ab}$ & $21.8 \mathrm{ab}$ & 32.5 & $25.7 \mathrm{ab}$ \\
"Cadaman" & 4 & $36.7 \mathrm{ab}$ & $26.6 \mathrm{ab}$ & $21.7 \mathrm{ab}$ & 33.2 & $26.2 \mathrm{ab}$ \\
"GF 677" & 4 & $37.7 \mathrm{ab}$ & $27.1 \mathrm{ab}$ & $22.7 \mathrm{ab}$ & 33.0 & $26.8 \mathrm{ab}$ \\
"PADAC 04-01" & 5 & $38.2 \mathrm{a}$ & $26.3 \mathrm{ab}$ & $23.7 \mathrm{a}$ & 33.6 & $28.9 \mathrm{a}$ \\
"PADAC 04-03" & 5 & $37.2 \mathrm{ab}$ & $27.3 \mathrm{ab}$ & $22.3 \mathrm{ab}$ & 33.8 & $26.3 \mathrm{ab}$ \\
"PADAC 99-05" & 4 & $37.6 \mathrm{ab}$ & $27.6 \mathrm{ab}$ & $23.1 \mathrm{ab}$ & 34.4 & $27.9 \mathrm{ab}$ \\
"PADAC 9902-01" & 3 & $37.5 \mathrm{ab}$ & $27.6 \mathrm{ab}$ & $22.7 \mathrm{ab}$ & 34.3 & $27.2 \mathrm{ab}$ \\
"PM 105 AD" & 3 & $35.8 \mathrm{~b}$ & $27.7 \mathrm{ab}$ & $20.7 \mathrm{~b}$ & 32.4 & $25.1 \mathrm{~b}$ \\
"Rootpac 70" & 4 & $36.5 \mathrm{ab}$ & $26.1 \mathrm{ab}$ & $21.1 \mathrm{~b}$ & 32.6 & $25.1 \mathrm{~b}$ \\
"Rootpac R" & 5 & $37.3 \mathrm{ab}$ & $26.9 \mathrm{~b}$ & $22.0 \mathrm{ab}$ & 32.5 & $26.7 \mathrm{ab}$ \\
\hline
\end{tabular}

Means followed by different letters in each column are significantly different at $p \leq 0.05$ according to HSD Tukey

Test. ns, not significant. ${ }^{a}$ number of trees evaluated.

"PADAC 04-01" had the highest $b^{*}$ and hue (h) values, despite not being statistically different from the rest of the rootstocks, except for "Adarcias", "PM 105 AD" and "Rootpac 70". Hue (h) showed a significant low and positive correlation with TA $(r=0.30, p \leq 0.01)$ (Table 8), meaning that less mature fruits will have more lightness hue angle (h color parameter). However, in other studies, a negative correlation was found between hue angle and TA [45]. In general, high hue angle values could indicate low acidity, in agreement with Génard et al. [58] and Ruíz and Egea [59]. Color measurements, in general, are good predictors for fruit quality parameters except for the fruit firmness because fruits with the same hue angle may have different firmness [60].

Table 8. Correlations between traits.

\begin{tabular}{lcccc}
\hline & Soluble Solids Content & Titratable Acidity & Leaf Mg & Leaf Mn \\
\hline Minimum temperature & $0.99^{*}$ & - & - & - \\
Maximum temperature & - & $-0.91 * *$ & - & - \\
Hue angle & - & $0.30 *$ & - & - \\
Leaf Ca & - & - & $0.75^{*}$ & $0.60 *$
\end{tabular}

The significance is designated by asterisks as follows: ${ }^{*}$, statistically significant differences at $p$-value $<0.05$; ${ }^{* *}$, statistically significant differences at $p$ value $<0.01$.

A hierarchical agglomerative cluster analysis was used to separate the rootstocks into three groups of increasing dissimilarity (Figure 3). This cluster showed that the rootstocks were not grouped according to their genetic origin, although results confirm that the plum based hybrids "PADAC 04-01" and "PADAC 99-05" induced fruits with the higher values on SSC and several color parameters $\left(\mathrm{L}^{*}, \mathrm{~b}^{*}\right.$, $\mathrm{C}^{*}$, and $\mathrm{h}$ ). In a rootstock trial established in a peach production area of Tunisia, the hybrid "PADAC 04-01" induced also a good agronomical performance and higher fruit quality (SSC) compared to other nine rootstocks budded with the flat peach "Subirana" [10], confirming its suitability for the Mediterranean area. 


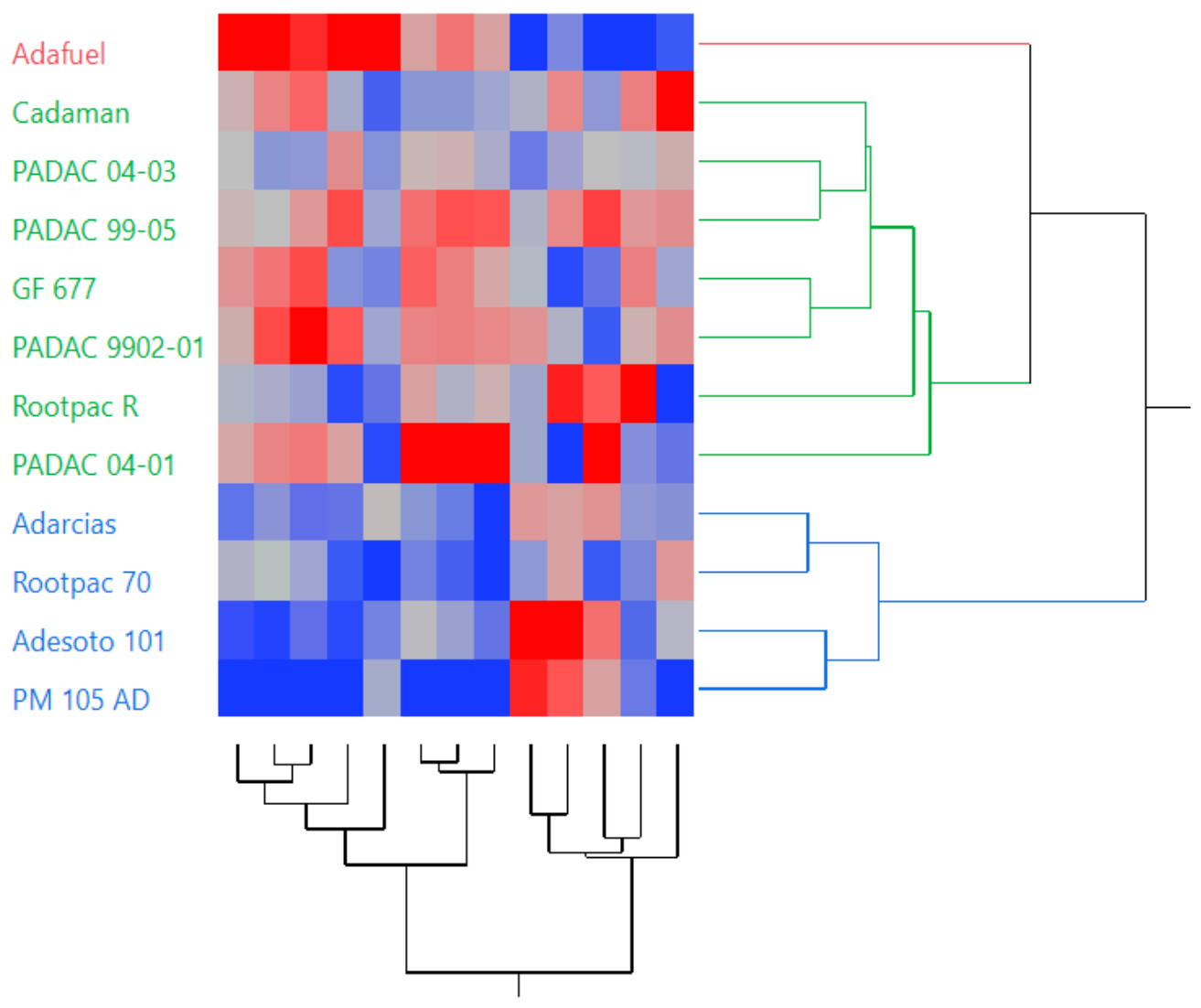

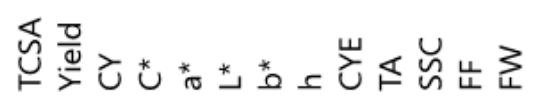

Figure 3. Hierarchical agglomerative cluster analysis grouped for the different rootstocks based on agronomical and fruit quality traits. Abbreviations: TCSA, trunk cross-sectional area; CY, cumulative yield; $\mathrm{L}^{*}, \mathrm{a}^{*}, \mathrm{~b}^{*}, \mathrm{C}^{*}$, and $\mathrm{h}$ color parameters; CYE, cumulative yield efficiency; TA, titratable acidity; SSC, soluble solids content; FF, flesh firmness; FW, fruit weight. Higher trait values are red whereas lower means are blue and average values are gray. Rootstocks labeled in red belong to Cluster 1, labeled in green to Cluster 2, and labeled in blue to Cluster 3. CY, CYE and TCSA data is from 2017; FF, FW, SSC and TA data is 2013-2017 average, and $L^{*}, a^{*}, b^{*}, C^{*}$ and $h$ data is 2013-2016 average.

In general, the plums "Adesoto 101" and "PM 105 AD", the peach-almond "Adarcias" and the interspecific plum based hybrids "PADAC 04-01", "PADAC 99-05" and "Rootpac R", showed the tendency to induce a better fruit quality, based on higher concentration of SSC, and other yield traits (Tables 5 and 6), demonstrating their commercial interest as rootstocks for peaches.

\subsection{Flower and Leaf Mineral Analysis}

The mean concentrations of several macro- and micro-mineral elements from flowers and mature leaves for each rootstock are shown in Tables 9 and 10. Significant effect of rootstock was found on all mineral elements evaluated, except for leaf $\mathrm{N}$ concentration and flower Fe concentration. Reference values on a dry weight basis have been developed for leaf elemental concentrations $[43,44]$. However, there are not reference values for flower elemental concentrations and very few works are available $[40,61,62]$. These experiments indicated that the peach flowers, which are quite large and develop before leaves, constitute a promising way of entry into the tree for essential nutrients such as $\mathrm{N}, \mathrm{K}, \mathrm{Mg}$, Fe and $\mathrm{Mn}$. On the basis that a shortage can be also crucial at the nutrient-demanding flowering stage, early season foliar applications of fertilizers can also improve peach fruit yield and quality [62]. 
Table 9. Rootstock effect on flower and leaf macro elements for "Big Top" nectarine cultivar budded on 12 Prunus rootstocks at the ninth year after planting

\begin{tabular}{|c|c|c|c|c|c|c|c|c|c|c|}
\hline \multirow{2}{*}{ Rootstock } & \multicolumn{2}{|c|}{ N (\%) } & \multicolumn{2}{|c|}{ P (\%) } & \multicolumn{2}{|c|}{$\mathrm{K}(\%)$} & \multicolumn{2}{|c|}{$\mathrm{Ca}(\%)$} & \multicolumn{2}{|c|}{$\operatorname{Mg}(\%)$} \\
\hline & Flower & Leaf & Flower & Leaf & Flower & Leaf & Flower & Leaf & Flower & Leaf \\
\hline "Adafuel" & $2.86 \mathrm{ab}$ & $3.11 \mathrm{~ns}$ & $0.38 \mathrm{a}$ & $0.20 \mathrm{ab}$ & $1.96 \mathrm{ab}$ & $1.88 \mathrm{c}$ & $0.47 \mathrm{a}$ & $2.07 \mathrm{ab}$ & $0.20 \mathrm{a}$ & $0.43 \mathrm{abc}$ \\
\hline "Adarcias" & $2.89 \mathrm{ab}$ & 3.00 & $0.33 \mathrm{ab}$ & $0.20 \mathrm{ab}$ & $2.01 \mathrm{ab}$ & $2.21 \mathrm{abc}$ & $0.38 \mathrm{abc}$ & $2.02 \mathrm{ab}$ & $0.19 \mathrm{abc}$ & $0.45 \mathrm{ab}$ \\
\hline "Adesoto 101" & $2.76 \mathrm{bc}$ & 2.98 & $0.35 \mathrm{ab}$ & $0.20 \mathrm{ab}$ & $1.98 \mathrm{ab}$ & $2.12 \mathrm{abc}$ & $0.44 \mathrm{ab}$ & $1.64 \mathrm{bc}$ & $0.17 \mathrm{c}$ & $0.37 \mathrm{bcd}$ \\
\hline “Cadaman” & $2.79 \mathrm{~b}$ & 2.99 & $0.33 \mathrm{ab}$ & $0.22 \mathrm{ab}$ & $1.97 \mathrm{ab}$ & $2.04 \mathrm{abc}$ & $0.41 \mathrm{abc}$ & $2.00 \mathrm{ab}$ & $0.19 \mathrm{abc}$ & $0.47 \mathrm{a}$ \\
\hline “GF 677” & $2.86 \mathrm{ab}$ & 3.05 & $0.37 \mathrm{a}$ & $0.20 \mathrm{ab}$ & $1.86 \mathrm{~b}$ & $2.03 \mathrm{abc}$ & $0.38 \mathrm{abc}$ & $2.01 \mathrm{ab}$ & $0.18 \mathrm{abc}$ & $0.45 \mathrm{ab}$ \\
\hline “PADAC 04-01" & $3.99 \mathrm{a}$ & 3.06 & $0.37 \mathrm{a}$ & $0.19 \mathrm{ab}$ & $1.96 \mathrm{ab}$ & $1.86 \mathrm{c}$ & $0.32 \mathrm{~d}$ & $1.32 \mathrm{c}$ & $0.17 \mathrm{c}$ & $0.34 \mathrm{~d}$ \\
\hline “PADAC 04-03” & $2.90 \mathrm{ab}$ & 2.98 & $0.35 \mathrm{ab}$ & $0.17 \mathrm{~b}$ & $1.97 \mathrm{ab}$ & $2.00 \mathrm{abc}$ & $0.39 \mathrm{abc}$ & $2.42 \mathrm{a}$ & $0.19 \mathrm{abc}$ & $0.48 \mathrm{a}$ \\
\hline "PADAC 9902-01" & $2.74 \mathrm{bc}$ & 3.10 & $0.36 \mathrm{a}$ & $0.22 \mathrm{ab}$ & $1.99 \mathrm{ab}$ & $2.09 \mathrm{abc}$ & $0.42 \mathrm{abc}$ & $1.77 \mathrm{bc}$ & $0.19 \mathrm{abc}$ & $0.47 \mathrm{a}$ \\
\hline “PADAC 99-05” & $2.87 \mathrm{ab}$ & 3.03 & $0.36 \mathrm{a}$ & $0.18 \mathrm{ab}$ & $1.95 \mathrm{ab}$ & $1.92 \mathrm{c}$ & $0.35 \mathrm{~cd}$ & $1.55 \mathrm{bc}$ & $0.19 \mathrm{abc}$ & $0.44 \mathrm{ab}$ \\
\hline “PM 105 AD" & $2.76 \mathrm{bc}$ & 3.05 & $0.35 \mathrm{ab}$ & $0.21 \mathrm{ab}$ & $2.07 \mathrm{a}$ & $2.43 \mathrm{ab}$ & $0.43 \mathrm{ab}$ & $1.29 \mathrm{c}$ & $0.17 \mathrm{c}$ & $0.36 \mathrm{~cd}$ \\
\hline “Rootpac 70" & $2.62 \mathrm{c}$ & 2.93 & $0.30 \mathrm{~b}$ & $0.24 \mathrm{a}$ & $1.99 \mathrm{ab}$ & $2.44 \mathrm{a}$ & $0.41 \mathrm{abc}$ & $2.02 \mathrm{ab}$ & $0.19 \mathrm{abc}$ & $0.51 \mathrm{a}$ \\
\hline “Rootpac R" & $2.86 \mathrm{ab}$ & 3.06 & $0.35 \mathrm{ab}$ & $0.21 \mathrm{ab}$ & $1.96 \mathrm{ab}$ & $2.16 \mathrm{abc}$ & $0.37 \mathrm{abc}$ & $1.51 \mathrm{bc}$ & $0.17 \mathrm{c}$ & $0.38 \mathrm{bcd}$ \\
\hline Adequate values ${ }^{a}$ & - & $2.5-3.8$ & - & $0.2-0.4$ & - & $1.7-2.7$ & - & $2.0-3.5$ & - & $0.4-0.7$ \\
\hline Adequate values $b$ & - & $3.0-3.5$ & - & $0.14-0.25$ & - & $2.0-3.0$ & - & $1.8-2.7$ & - & $0.3-0.8$ \\
\hline
\end{tabular}

${ }^{a}$ According to Villar and Villar [44]. ${ }^{\mathrm{b}}$ According to Leece [43]. Means followed by different letters in each column are significantly different at $p \leq 0.05$ according to HSD Tukey test. $\mathrm{ns}$, not significant. Flowers were sampled at full bloom stage and leaves at 120 days after full bloom. 
Table 10. Rootstock effect on flower and leaf micro elements for "Big Top" nectarine cultivar budded on 12 Prunus rootstocks at the ninth year after planting.

\begin{tabular}{|c|c|c|c|c|c|c|c|c|}
\hline \multirow{2}{*}{ Rootstock } & \multicolumn{2}{|c|}{$\mathrm{Fe}\left(\mathrm{mg} \mathrm{kg}^{-1}\right)$} & \multicolumn{2}{|c|}{$\mathrm{Cu}\left(\mathrm{mg} \mathrm{kg}{ }^{-1}\right)$} & \multicolumn{2}{|c|}{ Mn (mg kg $\left.{ }^{-1}\right)$} & \multicolumn{2}{|c|}{ Zn (mg kg $\left.{ }^{-1}\right)$} \\
\hline & Flower & Leaf & Flower & Leaf & Flower & Leaf & Flower & Leaf \\
\hline "Adafuel" & $144.7 \mathrm{~ns}$ & $50.6 \mathrm{ab}$ & $47.0 \mathrm{c}$ & $8.3 \mathrm{ab}$ & $22.3 \mathrm{ab}$ & $43.3 \mathrm{a}$ & $45.3 \mathrm{abc}$ & $19.0 \mathrm{ab}$ \\
\hline "Adarcias" & 147.0 & $76.7 \mathrm{ab}$ & $65.3 \mathrm{bc}$ & $6.3 \mathrm{~cd}$ & $25.3 \mathrm{ab}$ & $42.5 \mathrm{a}$ & $43.8 \mathrm{abc}$ & $16.0 \mathrm{~b}$ \\
\hline “Adesoto 101" & 164.3 & $75.0 \mathrm{ab}$ & $75.0 \mathrm{ab}$ & $8.0 \mathrm{abc}$ & $22.0 \mathrm{ab}$ & $27.7 \mathrm{bc}$ & $47.0 \mathrm{abc}$ & $22.5 \mathrm{ab}$ \\
\hline "Cadaman" & 135.5 & $71.5 \mathrm{ab}$ & $67.5 \mathrm{bc}$ & $6.5 \mathrm{abc}$ & $28.3 \mathrm{a}$ & $39.7 \mathrm{a}$ & $45.0 \mathrm{abc}$ & $18.7 \mathrm{ab}$ \\
\hline “GF 677” & 130.8 & $72.2 \mathrm{ab}$ & $64.8 \mathrm{bc}$ & $8.0 \mathrm{abc}$ & $18.0 \mathrm{ab}$ & $38.0 \mathrm{ab}$ & $47.8 \mathrm{abc}$ & $21.0 \mathrm{ab}$ \\
\hline “PADAC 04-01" & 135.4 & $75.4 \mathrm{ab}$ & $72.2 \mathrm{~b}$ & $7.4 \mathrm{abc}$ & $21.6 \mathrm{ab}$ & $34.4 \mathrm{abc}$ & $37.4 \mathrm{bc}$ & $17.8 \mathrm{ab}$ \\
\hline “PADAC 04-03" & 133.5 & $72.7 \mathrm{ab}$ & $64.8 \mathrm{bc}$ & $6.2 \mathrm{~d}$ & $20.3 \mathrm{ab}$ & $38.5 \mathrm{ab}$ & $57.0 \mathrm{a}$ & $25.5 \mathrm{a}$ \\
\hline “PADAC 9902-01" & 134.7 & $70.7 \mathrm{ab}$ & $56.0 \mathrm{bc}$ & $8.0 \mathrm{abc}$ & $20.7 \mathrm{ab}$ & $36.7 \mathrm{abc}$ & $40.7 \mathrm{abc}$ & $19.7 \mathrm{ab}$ \\
\hline “PADAC 99-05” & 129.8 & $81.5 \mathrm{a}$ & $68.5 \mathrm{bc}$ & $8.2 \mathrm{bcd}$ & $20.3 \mathrm{ab}$ & $32.0 \mathrm{abc}$ & $52.0 \mathrm{ab}$ & $21.7 \mathrm{ab}$ \\
\hline “PM 105 AD” & 146.7 & $64.0 \mathrm{~b}$ & $94.7 \mathrm{a}$ & $10.0 \mathrm{a}$ & $19.3 \mathrm{ab}$ & $25.7 \mathrm{c}$ & $44.0 \mathrm{abc}$ & $22.0 \mathrm{ab}$ \\
\hline “Rootpac 70" & 150.0 & $74.5 \mathrm{ab}$ & $62.0 \mathrm{bc}$ & $6.8 \mathrm{abc}$ & $17.3 \mathrm{~b}$ & $35.7 \mathrm{abc}$ & $34.7 \mathrm{c}$ & $18.5 \mathrm{ab}$ \\
\hline “Rootpac R" & 141.3 & $82.0 \mathrm{a}$ & $68.8 \mathrm{bc}$ & $7.3 \mathrm{abc}$ & $19.7 \mathrm{ab}$ & $38.5 \mathrm{ab}$ & $38.3 \mathrm{bc}$ & $21.0 \mathrm{ab}$ \\
\hline Adequate values ${ }^{a}$ & - & 80-175 & - & $5-20$ & - & $45-60$ & - & $30-50$ \\
\hline Adequate values ${ }^{b}$ & - & $100-250$ & - & $5-16$ & - & $40-160$ & - & $20-50$ \\
\hline
\end{tabular}

a According to Villar and Villar [44]. ${ }^{\mathrm{b}}$ According to Leece [43]. Means followed by different letters in each column are significantly different at $p \leq 0.05$ according to HSD Tukey test. ns, not significant. Flowers were sampled at full bloom stage and leaves at120 days after full bloom. 
In this study, all rootstocks induced optimum leaf values for the assessed macro-elements according to Villar and Villar [44], except "PADAC 04-03" and "PADAC 99-05" for P, and "Adesoto 101", "PADAC 04-01", "PM 105 AD" and "Rootpac R" for Ca and Mg, which had lower values than the optimum. Nevertheless, P, Ca and Mg values were adequate for all rootstocks agreeing to Leece [43], with the exception of the plum based rootstocks "PADAC 04-01", "PADAC 99-05", "PM 105 AD" and "Rootpac R" showing marginal values for $\mathrm{Ca}$. The tendency of plum based rootstocks to show lower leaf Ca values were also reported by comparing plum and peach based rootstocks in a calcareous soil of Tunisia [63].

Most rootstocks had leaf Fe, Mn and Zn deficiencies or close to deficiency (Table 10), according to reference values $[43,44]$. This could suggest according to the field fertilization that the roots from most of the rootstocks evaluated in this study have problems with uptake of these nutrients from the soil solution, due to the bicarbonate ions present into the typical soil solution of calcareous soils with high $\mathrm{pH}$, making their concentrations in leaves lower than the optimum. The tendency of "Rootpac $\mathrm{R}$ " and "PADAC 99-05" to induce higher leaf Fe concentration could indicate higher tolerance to iron-chlorosis in calcareous soils. Despite the low leaf Fe values, no iron chlorosis symptoms were observed on all rootstocks evaluated. According to reference values proposed by Leece [43], all rootstocks showed Mn values lower than optimum except "Adafuel" and "Adarcias", showing the interest of these rootstocks in this type of soils. Mn deficiency has been also reported for peach rootstocks in heavy and calcareous soils $[33,40]$, probably due to the lack of solubility of this element in soils with a high $\mathrm{pH}$. Furthermore, increased $\mathrm{Ca}$ in soil or an excess of phosphoric acid fertilization might decrease or block Mn uptake $[61,64,65]$.

Based on adequate values reported by Leece [43] and Villar and Villar [44], DOP index was calculated for each element separately (Tables 11 and 12) and for all elements together (Table 12). Significant differences among rootstocks were found on $\mathrm{Ca}, \mathrm{Mg}, \mathrm{Cu}$ and $\mathrm{Mn}$ elements for both ways of calculating the DOP index. Among rootstocks, "PADAC 04-03" was the most and the least balanced

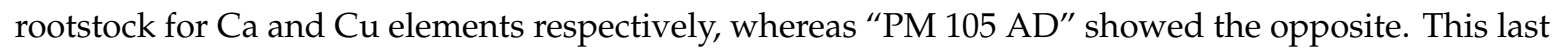
one also showed wider imbalanced Mn value, whereas "Adafuel" and "Adarcias" showed the contrary. However, for the $\Sigma$ DOP which had a high correlation between Leece [43] and Villar and Villar [44] $(r=0.86, p<0.0001)$, there were not significant differences among rootstocks.

Based on hierarchical agglomerative cluster analysis, three clusters were identified in both flower (Figure 4) and leaf (Figure 5) mineral status.

With regards to flower nutrient concentrations (Figure 4), the first group, which included "Adafuel" through "Cadaman", was characterized by rootstocks with high $\mathrm{Mg}$, medium to low $\mathrm{Zn}$, and very low $\mathrm{Cu}$ (Figure 4). In addition, "Adafuel" had high $\mathrm{P}$ and $\mathrm{Ca}$ concentrations and very low $\mathrm{Cu}$, whereas "Cadaman" had high Mn (Tables 9 and 10, Figure 4), in agreement with Zarrouk et al. [40] when those rootstocks were budded with the "Queen Giant" nectarine and the "Tebana" peach in a similar calcareous soil. The second cluster, which included rootstocks from "GF 677" to "Rootpac 70", had medium to high $\mathrm{N}$ and $\mathrm{P}$ values, and medium to low $\mathrm{Mn}, \mathrm{K}, \mathrm{Fe}, \mathrm{Cu}$ and $\mathrm{Ca}$ values (Figure 4). The last cluster, "Adesoto 101" through "Rootpac R", showed low values of N and P, and medium to high values of $\mathrm{K}, \mathrm{Fe}, \mathrm{Cu}$ and $\mathrm{Ca}$. When mineral element concentrations of flowers are compared with those obtained in leaves, only the values of $\mathrm{Ca}, \mathrm{Mg}$, and $\mathrm{Mn}$ appeared lower than in leaves, as reported for pear [62], peach [40], and cherry trees [61].

Concerning leaf nutrient concentrations, the first group, which included "Adafuel" through "PADAC 04-03", had medium to high Ca, Mg and Mn values, and low Fe and K values (Figure 5). "Adafuel" had also high N and Mn values in agreement with Zarrouk et al. [40]. PADAC 04-03 had high $\mathrm{Zn}$ and Ca values in agreement with Reig et al. [11]. The second cluster included "Adarcias"

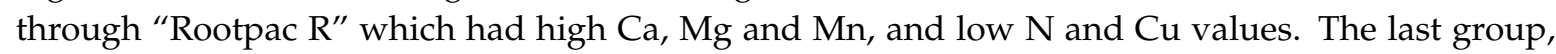
"Adesoto 101" through "PM 105 AD", had medium to high N, Cu, Fe and Zn, and low Ca, Mg and Mn values. Reig et al. [11] also reported high leaf K values on "PM 105 AD" and high Fe values on "Rootpac 70". 
Several strong and moderate correlations were found when grouping the macro- and micronutrient values for both flowers and leaves. Thus, leaf Ca was highly and positively correlated with leaf $\mathrm{Mg}$ $(r=0.75, p \leq 0.01)$ and moderately and positively correlated with leaf $\mathrm{Mn}(r=0.60, p \leq 0.01)$ (Table 8). It is worthy to mention that $\mathrm{Mg}$ had a moderate positive correlation when flower and leaf samples were compared $(r=0.49, p \leq 0.01)$, suggesting that $\mathrm{Mg}$ flower analysis could be used to detect and treat any deficiencies at an earlier stage in peach trees in calcareous soils.

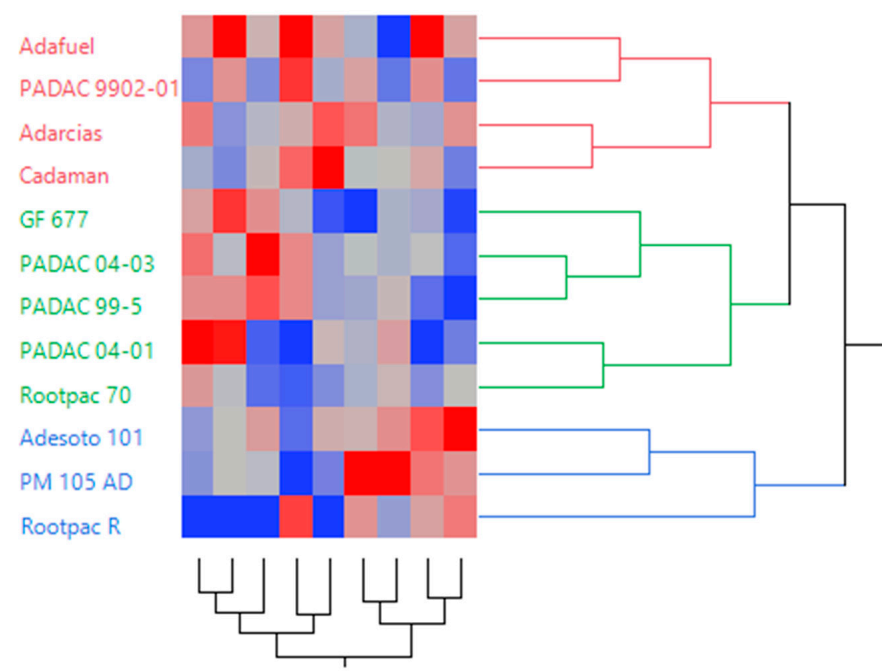

$$
\begin{aligned}
& z a, \frac{\pi}{\Sigma} \sum x \exists \text { U } \\
& u^{\prime} u^{\prime} u^{\prime} u^{\prime} u^{\prime} u^{\prime} u^{\prime} u^{\prime} u
\end{aligned}
$$

Figure 4. Rootstocks and flower nutrients grouped by similarities in mineral nutrient concentration mean values. Higher trait values are red whereas lower means are blue and average values are gray. Rootstocks labeled in red belong to Cluster 1, labeled in green to Cluster 2, and labeled in blue to Cluster 3.



Figure 5. Rootstocks and leaf nutrients grouped by similarities in mineral nutrient concentration mean values. Higher trait values are red whereas lower means are blue and average values are gray. Rootstocks labeled in red belong to Cluster 1, labeled in green to Cluster 2, and labeled in blue to Cluster 3. 
Table 11. Rootstock effect on DOP index for each macro elements of "Big Top" cultivar on twelve rootstocks.

\begin{tabular}{|c|c|c|c|c|c|c|c|c|c|c|}
\hline \multirow{2}{*}{ Rootstock } & \multicolumn{2}{|c|}{ N (\%) } & \multicolumn{2}{|c|}{$\mathbf{P}(\%)$} & \multicolumn{2}{|c|}{$\mathrm{K}(\%)$} & \multicolumn{2}{|c|}{ Ca $(\%)$} & \multicolumn{2}{|c|}{$\operatorname{Mg}(\%)$} \\
\hline & $\mathrm{DOP}^{a}$ & $\mathrm{DOP}^{b}$ & $\operatorname{DOP}^{a}$ & $\mathrm{DOP}^{b}$ & DOP $a$ & $\mathrm{DOP}^{b}$ & $\operatorname{DOP}^{a}$ & $\mathrm{DOP}^{b}$ & $\operatorname{DOP}^{a}$ & $\mathrm{DOP}^{b}$ \\
\hline "Adafuel" & $-4.1 \mathrm{~ns}$ & $-1.1 \mathrm{~ns}$ & $4.3 \mathrm{~ns}$ & $-32.2 \mathrm{~ns}$ & $-24.7 \mathrm{~ns}$ & $-14.4 \mathrm{~ns}$ & $-8.0 \mathrm{ab}$ & $-24.7 \mathrm{ab}$ & $-21.2 a b c$ & $-21.2 \mathrm{abc}$ \\
\hline "Adesoto 101" & -8.3 & -5.4 & 3.8 & -32.5 & -15.1 & -3.5 & $-27.0 \mathrm{ab}$ & $-40.2 \mathrm{ab}$ & $-32.7 \mathrm{bc}$ & $-32.7 b c$ \\
\hline "Cadaman" & -8.0 & -5.1 & 14.5 & -25.6 & -18.1 & -6.9 & $-11.0 \mathrm{ab}$ & $-27.2 \mathrm{ab}$ & $-11.8 \mathrm{ab}$ & $-11.8 \mathrm{ab}$ \\
\hline “GF 677” & -6.2 & -3.2 & 5.1 & -31.7 & -18.7 & -7.6 & $-10.3 \mathrm{ab}$ & $-26.6 a b$ & $-18.2 a b c$ & $-18.2 \mathrm{abc}$ \\
\hline “PADAC 99-05” & -6.8 & -3.8 & -6.4 & -39.2 & -23.1 & -12.6 & $-30.9 \mathrm{ab}$ & $-43.4 \mathrm{ab}$ & $-19.5 a b c$ & $-19.5 \mathrm{abc}$ \\
\hline “PADAC 9902-01" & -4.5 & -1.5 & 111 & -27.8 & -16.5 & -5.1 & $-21.3 \mathrm{ab}$ & $-35.6 \mathrm{ab}$ & $-13.9 a b c$ & $-13.9 \mathrm{abc}$ \\
\hline "PM 105 AD" & -6.3 & -3.3 & 9.4 & -28.9 & -2.7 & 10.6 & $-42.4 \mathrm{~b}$ & $-52.8 b$ & $-35.1 b c$ & $-35.1 b c$ \\
\hline “Rootpac 70" & -9.7 & -6.8 & 20.5 & -21.7 & -2.2 & 11.1 & $-10.2 \mathrm{ab}$ & $-26.5 a b$ & $-7.3 \mathrm{a}$ & $-7.3 \mathrm{a}$ \\
\hline "Rootpac R" & -5.6 & -2.6 & 7.7 & -30.0 & -13.3 & -1.5 & $-32.7 b$ & $-44.9 \mathrm{~b}$ & $-30.9 b c$ & $-30.9 b c$ \\
\hline
\end{tabular}

a According to Leece [43]. ${ }^{\mathrm{b}}$ According to Villar and Villar [44]. Means followed by different letters in each column are significantly different at $p \leq 0.05$ according to HSD Tukey Test. ns, not significant. 
Table 12. Rootstock effect on DOP index for each microelements of "Big Top" cultivar on twelve rootstocks.

\begin{tabular}{|c|c|c|c|c|c|c|c|c|c|c|}
\hline \multirow{2}{*}{ Rootstock } & \multicolumn{2}{|c|}{$\mathrm{Fe}\left(\mathrm{mg} \mathrm{kg}^{-1}\right)$} & \multicolumn{2}{|c|}{$\mathrm{Cu}\left(\mathrm{mg} \mathrm{kg}^{-1}\right)$} & \multicolumn{2}{|c|}{ Mn (mg kg $\left.{ }^{-1}\right)$} & \multicolumn{2}{|c|}{$\mathrm{Zn}\left(\mathrm{mg} \mathrm{kg} \mathrm{kg}^{-1}\right)$} & \multirow{2}{*}{$\sum \operatorname{DOP}^{a}$} & \multirow{2}{*}{$\sum \mathrm{DOP}^{b}$} \\
\hline & $\operatorname{DOP}^{a}$ & $\mathrm{DOP}^{b}$ & $\mathrm{DOP}^{a}$ & $\mathrm{DOP}^{b}$ & $\mathrm{DOP}^{a}$ & $\mathrm{DOP}^{b}$ & $\mathrm{DOP}^{a}$ & $\mathrm{DOP}^{b}$ & & \\
\hline "Adafuel" & $-58.3 \mathrm{~ns}$ & $-42.7 \mathrm{~ns}$ & $-20.6 \mathrm{ab}$ & $-33.3 a b$ & $-56.7 \mathrm{a}$ & $-17.5 \mathrm{a}$ & $-45.7 \mathrm{~ns}$ & $-52.5 \mathrm{~ns}$ & $259.8 \mathrm{~ns}$ & $239.6 \mathrm{~ns}$ \\
\hline "Adarcias" & -56.2 & -39.9 & $-39.7 b$ & $-49.3 b$ & $-57.5 \mathrm{a}$ & $-19.0 \mathrm{a}$ & -54.3 & -60.0 & 277.7 & 268.2 \\
\hline "Adesoto 101" & -57.1 & -41.2 & $-23.8 \mathrm{ab}$ & $-36.0 \mathrm{ab}$ & $-72.2 \mathrm{ab}$ & $-47.1 \mathrm{ab}$ & -35.7 & -43.7 & 285.7 & 290.2 \\
\hline "Cadaman" & -59.1 & -43.9 & $-38.1 b$ & $-48.0 \mathrm{~b}$ & $-59.5 \mathrm{ab}$ & $-22.8 \mathrm{ab}$ & -46.4 & -53.1 & 269.3 & 247.5 \\
\hline “GF 677” & -58.7 & -43.3 & $-23.8 \mathrm{ab}$ & $-36.0 \mathrm{ab}$ & $-62.0 \mathrm{ab}$ & $-27.6 \mathrm{ab}$ & -40.0 & -47.5 & 262.1 & 246.1 \\
\hline "PADAC 04-01" & -56.9 & -40.8 & $-29.5 \mathrm{ab}$ & $-40.8 \mathrm{ab}$ & $-65.6 \mathrm{ab}$ & $-34.5 \mathrm{ab}$ & -49.1 & -55.5 & 322.9 & 314.6 \\
\hline “PADAC 04-03" & -58.4 & -42.9 & $-40.5 b$ & $-50.0 \mathrm{~b}$ & $-61.5 a b$ & $-26.7 \mathrm{ab}$ & -27.1 & -36.2 & 270.2 & 250.1 \\
\hline “PADAC 9902-01" & -53.4 & -36.1 & $-21.4 \mathrm{ab}$ & $-34.0 \mathrm{ab}$ & $-68.0 \mathrm{ab}$ & $-39.0 \mathrm{ab}$ & -37.8 & -45.6 & 271.3 & 273.3 \\
\hline "PADAC 99-05" & -59.6 & -44.6 & $-23.8 \mathrm{ab}$ & $-36.0 \mathrm{ab}$ & $-63.3 a b$ & $-30.1 \mathrm{ab}$ & -43.8 & -50.8 & 259.7 & 247.0 \\
\hline “PM 105 AD” & -63.4 & -49.8 & $-4.8 \mathrm{a}$ & $-20.0 \mathrm{a}$ & $-74.3 \mathrm{~b}$ & $-51.1 \mathrm{~b}$ & -37.1 & -45.0 & 283.6 & 297.3 \\
\hline “Rootpac 70" & -57.4 & -41.6 & $-35.7 b$ & $-46.0 \mathrm{~b}$ & $-64.2 \mathrm{ab}$ & $-31.9 \mathrm{ab}$ & -47.1 & -53.7 & 260.4 & 248.7 \\
\hline "Rootpac R" & -53.1 & -35.7 & $-30.1 \mathrm{ab}$ & $-41.3 \mathrm{ab}$ & $-61.5 \mathrm{ab}$ & $-26.7 \mathrm{ab}$ & -40.0 & -47.5 & 280.8 & 270.9 \\
\hline
\end{tabular}

a According to Leece [43]. ${ }^{\mathrm{b}}$ According to Villar and Villar [44]. Means followed by different letters in each column are significantly different at $p \leq 0.05$ according to HSD Tukey Test. ns, not significant. 


\section{Conclusions}

This study demonstrates that the rootstock greatly influences some important tree and fruit traits, such as tree survival, vigor, yield efficiency, leaf and flower mineral nutrition and SSC. The vigor-controlling rootstocks ("Adarcias", "Adesoto 101" and other plums), and several interspecific plum based hybrids ("PADAC 04-01", "PADAC 99-05" and "Rootpac R"), showed the tendency to induce a better fruit quality. In addition, "Adarcias", "PADAC 04-01", and "Rootpac R" were the best adapted rootstocks in heavy-calcareous soil conditions and demonstrating their commercial interest as rootstocks for peaches. Therefore, new interspecific rootstocks are available based on their good performance and tolerance to abiotic stresses and adapted to Mediterranean conditions.

Author Contributions: C.F.iF.: Formal analysis, investigation, data curation, writing, review, editing, visualization, supervision. G.R.: Formal analysis, investigation, data curation, writing, review, editing, visualization, supervision. L.M.: Data curation, review. P.M.: Data curation, review. J.Á.B.: Data curation, review. M.Á.M.: Conceptualization, methodology, validation, investigation, resources, review, visualization, supervision, project administration, funding acquisition. All authors have read and agreed to the published version of the manuscript.

Funding: Financial support was provided by the Spanish Ministry of Science and Innovation (grants AGL2011-24576, RFP 2015-00019 and RTI2018-094176-R-C33) co-funded by FEDER and the Regional Government of Aragon (grants A44 and T07-17R). C. Font i Forcada was also supported by the Ministry of Science and Innovation with a "Juan de la Cierva-Incorporación" grant (IJCI-2015-23397).

Acknowledgments: We are grateful to J. Pinochet (Agromillora Iberia S.L.) for providing plant material, to M.P. Soteras for help in the analysis of fruit quality, and A. Palacios for technical assistance in mineral analysis.

Conflicts of Interest: The authors declare no conflict of interest.

\section{References}

1. Milošević, T.; Milošević, N.; Mladenović, J. Combining fruit quality and main antioxidant attributes in the sour cherry: The role of new clonal rootstock. Sci. Hortic. 2020, 265, 109236. [CrossRef]

2. Reig, G.; Mestre, L.; Betrán, J.A.; Pinochet, J.; Moreno, M.A. Agronomic and physicochemical fruit properties of "Big Top" nectarine budded on peach and plum based rootstocks in Mediterranean conditions. Sci. Hortic. 2016, 210, 85-92. [CrossRef]

3. Reig, G.; Alegre, S.; Cantín, C.M.; Gatius, F.; Puy, J.; Iglesias, I. Tree ripening and postharvest firmness loss of eleven commercial nectarine cultivars under Mediterranean conditions. Sci. Hortic. 2017, 219, 335-343. [CrossRef]

4. Fernández, V.; Del Rio, V.; Pumarino, L.; Igartua, E.; Abadía, J.; Abadía, A. Foliar fertilization of peach (Prunus persica (L.) Batsch) with different iron formulations: Effects on re-greening, iron concentration and mineral composition in treated and untreated leaf surfaces. Sci. Hortic. 2008, 117, 241-248. [CrossRef]

5. Paniagua, L.L.; García-Martín, A.; Moral, F.J.; Rebollo, F.J. Aridity in the Iberian Peninsula (1960-2017): Distribution, tendencies, and changes. Theor. Appl. Climatol. 2019, 138, 811-830. [CrossRef]

6. Ozturk, T.; Zeynep, P.C.; Turkes, M.; Kurnaz, M.L. Projections of climate change in the Mediterranean Basin by using down scaled global climate model outputs. Int. J. Climatol. 2015, 35, 4276-4292. [CrossRef]

7. Byrne, D.H.; Raseira, M.C.; Bassi, D.; Piagnani, M.C.; Gasic, K.; Reighard, G.L.; Moreno, M.A.; Pérez, S. Peach. In Fruit Breeding, Handbook of Plant Breeding 8; Badenes, M.L., Byrne, D.H., Eds.; Springer Science + Business Media, LLC: Düsseldorf, Germany, 2012; pp. 505-565.

8. Reighard, G.; Loreti, F. Rootstock development. In The Peach: Botany, Production and Uses; Layne, D.R., Bassi, D., Eds.; CABI: Wallingford, UK, 2008; pp. 193-220.

9. Moreno, M.A. Breeding and selection of Prunus rootstocks at the Aula Dei Experimental Station, Zaragoza, Spain. Acta Hortic. 2004, 658, 519-528. [CrossRef]

10. Yahmed, J.B.; Ghrab, M.; Moreno, M.A.; Pinochet, J.; Mimoun, M.B. Performance of "Subirana" flat peach cultivar budded on different Prunus rootstocks in a warm production area in North Africa. Sci. Hortic. 2016, 206, 24-32. [CrossRef]

11. Reig, G.; Garanto, X.; Mas, N.; Iglesias, I. Long-term agronomical performance and iron chlorosis susceptibility of several Prunus rootstocks grown under loamy and calcareous soil conditions. Sci. Hortic. 2020, 262, 109035. [CrossRef] 
12. Reig, G.; Alegre, S.; Gatius, F.; Iglesias, I. Adaptability of peach cultivars [Prunus persica (L.) Batsch] to the climatic conditions of the Ebro Valley, with the special focus on fruit quality. Sci. Hortic. 2015, 190, 149-160. [CrossRef]

13. Minas, I.S.; Tanou, G.; Molassiotis, A. Environmental and orchard bases of peach fruit quality. Sci. Hortic. 2018, 235, 307-322. [CrossRef]

14. Font i Forcada, C.; Reig, G.; Giménez, R.; Mignard, P.; Mestre, L.; Moreno, M.A. Sugars and organic acids profile and antioxidant compounds of nectarine fruits influenced by different rootstocks. Sci. Hortic. 2019, 248, 145-153. [CrossRef]

15. Iglesias, I.; Giné-Bordonada, J.; Garanto, X.; Reig, G. Rootstock affects fruit quality and phytochemical composition of "Big Top" nectarine grown under hot climatic conditions. Sci. Hortic. 2019, 256, 108586. [CrossRef]

16. Pinochet, J.; Calvet, C.; Hernández-Dorrego, A.; Bonet, A.; Felipe, A.; Moreno, M.A. Resistance of peach and plum rootstocks from Spain, France, and Italy to root-knot nematode Meloidogyne javanica. HortScience 1999, 34, 1259-1262. [CrossRef]

17. Mestre, L.; Reig, G.; Betrán, J.A.; Moreno, M.A. Influence of plum rootstocks on agronomic performance, leaf mineral nutrition and fruit quality of "Catherina" peach cultivar in heavy-calcareous soil conditions. Span. J. Agric. Res. 2017, 15, e0901. [CrossRef]

18. Zarrouk, O.; Gogorcena, Y.; Moreno, M.A.; Pinochet, J. Graft compatibility between peach cultivars and Prunus rootstocks. HortScience 2006, 41, 1389-1394. [CrossRef]

19. Salazar, A.E.; Torrents, J.; Bordas, M.; Val, J.; Moreno, M.A. Graft compatibility for new released Prunus rootstocks. Acta Hortic. 2018, 1228, 175-180. [CrossRef]

20. Jiménez, S.; Pinochet, J.; Romero, J.; Gogorcena, Y.; Moreno, M.A.; Espada, J.L. Performance of peach and plum based rootstocks of different vigor on a late peach cultivar in replant and calcareous conditions. Sci. Hortic. 2011, 129, 58-63. [CrossRef]

21. Iglesias, I. Costes de producción, sistemas de formación y mecanización en frutales, con especial referencia al melocotonero. Rev. Frutic. 2019, 69, 50-59.

22. Orazem, P.; Stampar, F.; Hudina, M. Quality analysis of "Redhaven" peach fruit grafted on 11 rootstocks of different genetic origin in a replant soil. Food Chem. 2011, 124, 1691-1698. [CrossRef]

23. Reighard, G.L.; Beckman, T.; Belding, R.; Black, B.; Byers, P.; Cline, J.; Cowgill, W.; Godin, R.; Johnson, R.S.; Kamas, J.; et al. Six-year performance of 14 Prunus rootstocks at 11 sites in the 2001 NC-140 peach trial. J. Am. Pomol. Soc. 2011, 65, 26-41.

24. Remorini, D.; Fei, C.; Loreti, F.; Massai, R. Observations on nine peach rootstocks grown in a replant soil. Acta Hortic. 2015, 1085, 131-138. [CrossRef]

25. Font i Forcada, C.; Gradziel, T.M.; Gogorcena, Y.; Moreno, M.A. Phenotypic diversity among local Spanish and foreign peach and nectarine [Prunus persica (L.) Batsch] accessions. Euphytica 2014, 197, 261-277. [CrossRef]

26. Moreno, M.A.; Tabuenca, M.C.; Cambra, R. Performance of Adafuel and Adarcias as peach rootstocks. HortScience 1994, 29, 1271-1273. [CrossRef]

27. Moreno, M.A.; Tabuenca, M.C.; Cambra, R. “Adesoto 101”, a plum rootstock for peaches and other stone fruit. HortScience 1995, 30, 1314-1315. [CrossRef]

28. Edin, M.; Garcin, A. Un nouveau porte greffe du pêcher Cadaman-Avimag. L'Arboriculture Fruitière 1994, 475, 20-23.

29. Felipe, A.J. "Felinem", “Garnem" and "Monegro" almond × peach hybrid rootstock. HortScience 2009, 44, 196-197. [CrossRef]

30. Bernhard, R.; Grasselly, C. Les pêchers $\times$ amandiers. L'Arboriculture Fruitière 1981, 328, 37-42.

31. Nicotra, A.; Moser, L. Two new plum rootstocks for peach and nectarines: "Penta" and "Tetra". Acta Hortic. 1997, 451, 269-271. [CrossRef]

32. Pinochet, J. "Replantpac" (Rootpac ${ }^{\circledR}$ R), a plum-almond hybrid rootstock for replant situations. HortScience 2010, 45, 299-301. [CrossRef]

33. Mestre, L.; Reig, G.; Betrán, J.A.; Pinochet, J.; Moreno, M.A. Influence of peach-almond hybrids and plum-based rootstocks on mineral nutrition and yield characteristics of "Big Top" nectarine in replant and heavy-calcareous soil conditions. Sci. Hortic. 2015, 192, 475-481. [CrossRef]

34. Okie, W.R. Plum rootstocks. In Rootstocks for Fruit Crops; Rom, R.C., Carlson, R.F., Eds.; John Wiley and Sons: New York, NY, USA, 1987; pp. 321-360. 
35. Salvador, R.; Martínez-Cob, A.; Cavero, J.; Playán, E. Seasonal on-farm irrigation performance in the Ebro basin (Spain): Crops and irrigation systems. Agric. Water Manag. 2011, 98, 577-587. [CrossRef]

36. Walkley, A.; Black, I.A. An examination of the Degtjareff method for determining soil organic matter and a proposed modification of the chromic acid titration. Soil Sci. 1934, 37, 29-38. [CrossRef]

37. Olsen, S.R.; Watanabe, F.S. A method to determine a phosphorus adsorption maximum of soils as measured by the langmuir isotherm. Soil Sci. Soc. Am. Proc. 1957, 21, 144-149. [CrossRef]

38. Gaucher, G. Traité de pédologie agricole: Le sol et ses caractéristiques agronomiques; Dunod: Paris, France, 1968; p. 578.

39. Ahn, J.S.; Lee, Y.K. Color distribution of a shade guide in the value, chroma, and hue scale. J. Prosthet. Dent. 2008, 100, 18-28. [CrossRef]

40. Zarrouk, O.; Gogorcena, Y.; Gómez-Aparisi, J.; Betrán, J.A.; Moreno, M.A. Influence of almond x peach hybrids rootstocks on flower and leaf mineral concentration, yield and vigor of two peach cultivars. Sci. Hortic. 2005, 106, 502-514. [CrossRef]

41. C.I.I. (Comité Inter-Institutos para el estudio de técnicas analíticas). Métodos de referencia para la determinación de elementos minerales en vegetales. Anales Edafología Agrobiología 1969, 38, 403-417.

42. Montañés, L.; Heras, L.; Abadía, J.; Sanz, M. Plant analysis interpretation based on a new index: Deviation from optimum percentage (DOP). J. Plant Nutr. 1993, 16, 1289-1308. [CrossRef]

43. Leece, D.R. Diagnostic leaf analysis for stone fruit. Peach (Prunus persica). Aust. J. Exp. Agric. Anim. Husb. 1975, 15, 138-139.

44. Villar, P.; Villar, J.M. Guia de la Fertilitat dels Sòls i la Nutrició Vegetal en Producció Integrada; Consell Català de Producció Integrada: Lleida, Spain, 2016; p. 126.

45. Font i Forcada, C.; Gogorcena, Y.; Moreno, M.A. Agronomical and fruit quality traits of two peach cultivars on peach-almond hybrid rootstocks growing on Mediterranean conditions. Sci. Hortic. 2012, 140, 157-163. [CrossRef]

46. Reig, G.; Font i Forcada, C.; Mestre, L.; Jiménez, S.; Betrán, J.A.; Moreno, M.A. Horticultural, leaf mineral and fruit quality traits of two "Greengage" plum cultivars budded on plum based rootstocks in Mediterranean conditions. Sci. Hortic. 2018, 232, 84-91. [CrossRef]

47. Tsipouridis, C.; Thomidis, T. Effect of 14 peach rootstocks on the yield, fruit quality, mortality, girth expansion and resistance to frost damages of "May Crest" peach variety and their susceptibility on Phytophthora citrophthora. Sci. Hortic. 2005, 103, 421-428. [CrossRef]

48. Olmo-Vega, A.; García-Sánchez, F.; Simón, I.S.-G.; Lidón, V.; Manuel, N.; Martínez-Nicolás, J.J. Physiological responses of three pomegranate cultivars under flooded conditions. Sci. Hortic. 2017, 224, 171-179. [CrossRef]

49. Ziegler, V.H.; Ploschuk, E.; Weibel, A.; Insausti, P. Short-term responses to flooding stress of three Prunus rootstocks. Sci. Hortic. 2017, 224, 135-141. [CrossRef]

50. Massai, R.; Loreti, F. Preliminary observations on nine peach rootstocks grown in a replant soil. Acta Hortic. 2004, 658, 185-192. [CrossRef]

51. Marra, F.P.; Lo Bianco, M.; La Mantia, L.; Caruso, T. Growth, yield and fruit quality of "Tropic Snow" peach on size-controlling rootstocks under dry Mediterranean climates. Sci. Hortic. 2013, 160, 274-282. [CrossRef]

52. Font i Forcada, C.; Gogorcena, Y.; Moreno, M.A. Fruit sugar profile and antioxidants of peach and nectarine cultivars on almond $\times$ peach hybrid rootstocks. Sci. Hortic. 2013, 164, 563-572. [CrossRef]

53. Lopestri, J.; Goodwin, I.; McGlasson, B.; Holford, P.; Golding, J. Variability in size and soluble solids concentration in peaches and nectarines. Hortic. Rev. 2014, 42, 253-311. [CrossRef]

54. Iglesias, I.; Echeverría, G. Differential effect of cultivar and harvest date on nectarine color: Quality and consumer acceptance. Sci. Hortic. 2009, 120, 41-50. [CrossRef]

55. Crisosto, C.H.; Crisosto, G.M. Relationship between ripe soluble solids concentration (RSSC) and consumer acceptance of high and low acid melting flesh peach and nectarine (Prunus persica (L.) Batsch) cultivars. Postharv. Biol. Technol. 2005, 38, 239-246. [CrossRef]

56. Usenik, V.; Kastelec, D.; Veberič, R.; Štampar, F. Quality changes during ripening of plums (Prunus domestica L.). Food Chem. 2008, 111, 830-836. [CrossRef]

57. Daza, A.; García-Galavís, P.A.; Grande, M.J.; Santamaría, C. Fruit quality parameters of "Pioneer" Japanese plums produced on eight different rootstocks. Sci. Hortic. 2008, 118, 206-211. [CrossRef]

58. Génard, M.; Souty, M.; Holmes, S.; Reich, M.; Breuils, L. Correlations among quality parameters of peach fruit. J. Sci. Food Agric. 1994, 66, 241-245. [CrossRef] 
59. Ruíz, D.; Egea, J. Phenotypic diversity and relationships of fruit quality traits in apricot (Prunus armeniaca L.) germplasm. Euphytica 2008, 163, 143-158. [CrossRef]

60. Lewallen, K.S.; Marini, R.P. Relationship between flesh firmness and ground color in peach as influenced by light and canopy position. J. Am. Hortic. Sci. 2003, 128, 163-170.

61. Jiménez, S.; Garín, A.; Gogorcena, Y.; Betrán, J.A.; Moreno, M.A. Flower and foliar analysis for prognosis of sweet cherry nutrition: Influence of different rootstocks. J. Plant Nutr. 2004, 27, 701-712. [CrossRef]

62. El-Jendoubi, H.; Igartua, E.; Abadía, J.; Abadía, A. Prognosis of iron chlorosis in pear (Pyrus communis L.) and peach (Prunus persica L. Batsch) trees using bud, flower and leaf mineral concentrations. Plant Soil 2012, 354, 121-139. [CrossRef]

63. Yahmed, J.B.; Ghrab, M.; Moreno, M.A.; Pinochet, J.; Mimoun, M.B. Leaf mineral nutrition and tree vigor of "Subirana" flat peach cultivar grafted on different Prunus rootstocks in a warm Mediterranean area. J. Plant Nutr. 2020, 43, 811-822. [CrossRef]

64. Johnson, R.S.; Uriu, K. Mineral nutrition. In Growing and Handling for Fresh Market: Division of Agriculture Resource; Larue, J., Johnson, R.S., Eds.; University of California: Oakland, CA, USA, 1989; pp. 68-81.

65. Moreno, M.A.; Adrada, R.; Aparicio, J.; Betrán, J.A. Performance of "Sunburst" sweet cherry grafted on different rootstocks. J. Hortic. Sci. Biotechnol. 2001, 76, 167-173. [CrossRef]

(C) 2020 by the authors. Licensee MDPI, Basel, Switzerland. This article is an open access article distributed under the terms and conditions of the Creative Commons Attribution (CC BY) license (http://creativecommons.org/licenses/by/4.0/). 